\title{
Towards a Macroprudential Surveillance and Remedial Policy Formulation System for Monitoring Financial Crisis
}

\author{
Biswa N. Bhattacharyay \\ CESIFO WORKING PAPER NO. 2803 \\ CATEGORY 7: MONETARY POLICY AND INTERNATIONAL FINANCE \\ SEPTEMBER 2009
}

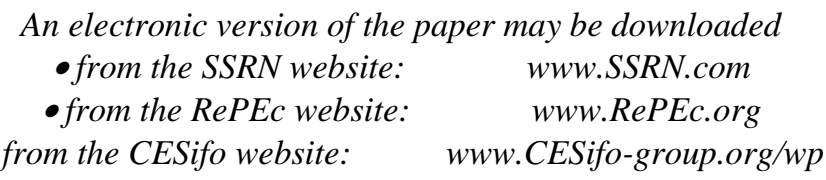




\title{
Towards a Macroprudential Surveillance and Remedial Policy Formulation System for Monitoring Financial Crisis
}

\begin{abstract}
Several developing economies witnessed a large number of systemic financial and currency crises since the 1980s which resulted in severe economic, social, and political problems. The devastating impact of the 1982 and 1994-95 Mexican crises, the 1997-98 Asian financial crisis, the 1998 Russian crisis and the ongoing financial crisis of 2008-2009 suggest that maintaining financial sector stability through reduction of vulnerability is highly crucial. The world is now witnessing an unprecedented systemic financial crisis originated from USA in September 2008 together with a deep worldwide economic recession, particularly in developed countries of Europe and North America. This calls for devising and using on a regular basis an appropriate and effective monitoring and policy formulation system for detecting and addressing vulnerabilities leading to crisis. This paper proposes a macroprudential/financial soundness monitoring, analysis and remedial policy formulation system that can be used by most developing countries with or without crisis experience as well as developed countries with limited data. It also discusses a process for identifying, and compiling a set of leading macroprudential indicators/financial soundness indicators. An empirical illustration using Philippines data is presented.
\end{abstract}

JEL Code: F30, E58, E44, G20, G10, G32, G28.

Keywords: economic and financial vulnerability, macroprudential indicators and financial soundness indicators analysis, macroprudential surveillance and policy, developing countries, financial sector, currency and financial crises, Early Warning Models, Stress Testing.

\author{
Biswa N. Bhattacharyay \\ Asian Development Bank Institute \\ Tokyo 100-6008, Japan \\ bbhattacharyay@adbi.org.
}

Special advisor to Dean. Asian Development Bank (ADB) institute, Tokyo and on Secondment from ADB, Manila. The views expressed in the paper are those of the author and do not necessarily reflects the views and policies of ADBI, the ADB, its Board of Directors or the government they represent. The author thanks Madhurima Bhattacharyay for providing research assistance. 


\title{
Towards Macroprudential Surveillance and Remedial Policy Formulation System for Monitoring Financial Crisis
}

\author{
Biswa N. Bhattacharyay ${ }^{2}$
}

\section{Introduction}

Over the last decade, many developing countries have become increasingly integrated into global financial markets through deregulation, liberalization, particularly through liberalization of the capital account, and privatization of the market. Several emerging market economies witnessed a large number of financial crises since the 1980s which resulted in severe economic, social, and political problems. The devastating impact of the 1982 and 1994-95 Mexican crises, the 1997-98 Asian financial crisis and the 1998 Russian crisis suggest that maintaining financial sector stability through reduction of vulnerability is highly crucial.

However, financial crises were not limited to developing countries only. In the last decade, several industrial countries, such as some countries in Europe (European currency crisis in 1992-93), Japan and some of the Nordic countries also witnessed financial crises that had significant macroeconomic consequences. Recently, the world has witnessed an unprecedented systemic financial crisis originating from the USA in September 2008. This has been followed by a deep worldwide economic recession. In this crisis, developed countries of Europe and North America were affected severely.

In order to reduce vulnerability to crisis, developing countries as well as developed countries should have sound economic policies, flexible exchange rate, effective institutions, good governance, particularly well supervised financial markets and an appropriate monitoring system for vulnerability leading to crisis. This calls for devising an appropriate monitoring and policy formulation system for detecting and addressing financial vulnerabilities.

Past and present crises show that we have not learned enough on how to prevent them. What can be learned from this is that it is extremely difficult to accurately predict crises, particularly their timing. So it is important to be prepared for crises if it cannot be fully prevented and to detect the crises early in order to minimize their impact and limit their damaging after effects.

As financial sectors are highly vulnerable to instability and systemic risk, monitoring these sectors as well as spillover effects of weaknesses in the real sector assumes great importance in light of the severity and frequency of financial crises, especially keeping in mind the combined currency and banking collapses of the past decade. The main question that arises is what can be done to reduce the damage of these events. Is it possible to maintain a moderate degree of stability in the financial markets of a region with liberalized capital flows? In any case, there is a

\footnotetext{
${ }^{2}$ Special advisor to Dean at the Asian Development Bank (ADB) institute and on a secondment from ADB. The views expressed in the paper are those of the author and do not necessarily reflects the views and policies of ADBI, the ADB, ITS Board of Directors or the government they represent. The author thanks Madhurima Bhattacharyay for providing research assistance.
} 
need for increased effort for reducing vulnerability to crisis. Therefore, an appropriate and effective system for early vulnerability detection and remedial policy formulation is clearly vital for reducing vulnerability to crisis.

Some progress has been made in identifying and compiling accurate and timely crisismonitoring indicators. The focus has now shifted towards the development of techniques for the proper analyses and interpretation of data since no universally accepted standard or system of macroprudential analysis exists. Many countries, particularly crisis-affected ones are now analyzing crisis-monitoring or macroprudential indicators (MPIs)/Financial Soundness Indicators (FSIs). However, this analysis does not usually lead to remedial policy formulation and actions. There seems to be a disconnect between the analysis of MPIs and the remedial policy formulation.

This paper proposes a macroprudential surveillance and remedial policy formulation system that can be used by most developing countries with or without crisis experience to detect economic and financial sector vulnerability, design appropriate policy responses and undertake preventing actions to address vulnerabilities. The proposed system outlines a process for identifying and compiling a set of leading MPIs, and methods for macroprudential analysis and a process for formulating remedial policy actions for addressing vulnerability. It focuses on high frequency monitoring financial sector vulnerability and spillover effects of weakness in the real sector for early detection of irregularities and swift remedial policy actions. Furthermore, an empirical illustration of the system using Philippines' data is presented.

\section{Need for a Comprehensive Monitoring System}

The cost of a financial crisis could be severe in terms of reserve losses, output decline and poverty. Usually, governments or taxpayers incur huge fiscal costs by any standard. Costs measured by output losses are comparatively less but still large. Financial sector vulnerability affects the macroeconomy through several channels, such as credit crunch, high interest spreads, low financial intermediation, lending caution, disruption of the payments system. It also affects the effectiveness of monetary policy due to low monetarization, volatility in monetary aggregates, rates unresponsiveness to open market operations, stickiness in interest rates, and high non-performing loans.

According to a paper on the Copenhagen Consensus, ${ }^{3}$ Eichengreen (2004) states, "The loss from the average or typical financial crisis is around 9\% of GDP (see Bordo et. al., 2001 for details), and the severe crises, such as those of Argentina and Indonesia, caused output or GDP to fall over 20\%, an economic loss higher than those incurred due to the Great Depression. According to Chen and Ravallion (2001), the 1997 Asian financial crisis increased the number of people below poverty line in the region by 22 million. Even though one can question the accuracy of such estimates, the avoidance of such crises could benefit emergingmarket economies by $\$ 107$ billion a year."

In 1997 and 1998, sudden outflows of capital from several East Asian countries, such as Indonesia, Republic of Korea, Malaysia, Philippines, and Thailand reeled from a devastating financial crisis, which resulted in severe economic, social, and political problems. Their open financial markets sparked a plunge in their currencies, stocks and other assets and severely damaged some of their financial institutions. Economies contracted and the standards of living of millions of people worsened. Economic development was set back for years in some areas.

\footnotetext{
${ }^{3}$ Paper written on Copenhagen Consensus and presented at Copenhagen on 25-28 May 2004.
} 
The Asian financial crisis has demonstrated how financial integration could expose developing counties to external shocks. These shocks reversed the success in poverty reduction in some countries from openness of the financial markets and caused a significant increase in poverty in the short to medium term. Following years of robust growth and strides in the standard of living, and export expansion, these economies suffered from a crippling devaluation, massive capital flight, corporate and banking failures, and spikes in unemployment. In a relatively short span of time, close to US\$100 billion of capital flew out of the region.

The Mexican Peso crisis of 1995 witnessed its worst recession in 60 years. The real GDP declined by $6 \%$ ((Goldstein et. al., 2000). According to a study by Baldaccci et al. (2002), the 1994-95 Mexican financial crisis gave rise to an increase in poverty and some cases, income inequality. The incidence of poverty as defined by poverty head count ratio increased by around $6 \%$ to reach $17 \%$ in 1996 from $10.6 \%$ in 1994, reversing the reduction in poverty made between 1992 and 1994. An important lesson to be learnt from the Asian financial crisis and the Mexican Peso crisis is that adequate social safety nets for households should be in place prior to the integration of domestic financial markets.

The economic loss in terms of reserves was $\$ 150$ billion to $\$ 200$ billion and an official exchange market intervention was undertaken during the Exchange Rate Mechanism Crisis (ERM) of 1992-93 to control the devaluation and/or floating of ERM currencies without any success.

The sub-prime mortgage market crisis, which originated in U.S. in September 2008, has had a devastating effect on the U.S. and EU's financial system through the bursting of the housing bubble, bankruptcies and the ensuing credit crisis. The crisis has led to a major global recession which has been coursed through three major channels, namely, export collapse, reversal of capital flows, and the weakening of market confidence. Experts are referring to this as the first global recession in the new era of globalization (Bhattacharyay and Dey, 2009). Ongoing financial and economic crisis has a devastating impact worldwide in terms of the economic and financial losses, and the full magnitude of its impact is yet to be assessed.

It is in this context that the effective monitoring of financial sectors as well as the assessment of the spillover effects of weaknesses in the real sector assumes great importance. The monitoring system should be able to detect the magnitude and nature of economic and financial vulnerability at an early stage and suggest appropriate policy actions to address them to prevent a potential financial or currency crisis. The monitoring and early warning system should not be very complicated so that high frequency monitoring can be performed.

The virulence of the contagion among neighboring countries as well as other trade partners highlights the need for a regional surveillance mechanism, particularly the peer review process to prevent future crises and financial instability or to minimize their impacts in the region. At the same time, recent financial crisis calls for an effective global surveillance system supported by appropriate and effective regional and national surveillance systems.

\section{Financial Vulnerability and Causes}

It is important to define what financial vulnerability is and what its causes are prior to developing a system for its monitoring. The first question is what the primary reasons behind crises are. Prior to 1970s, the majority of crises were "Current Account" or "Balance of Payment Problem" crises. Theses crises were primarily due to inconsistency of macroeconomic policies, such as highly expansionary domestic policy with fixed exchange rate pegs or a massive deterioration in the terms of trade with a highly restrictive trade regime. During 1990s, emerging markets 
witnessed rapidly growing capital inflows resulting in much higher debt in the private sector compared to the official sector. Therefore, most crises in 1990s were so called "Capital Account Crises" that occur when owners of the country's debt lose confidence in country's capability to service its debt in the future. Countries with fixed exchange rate pegs and open capital accounts are highly vulnerable to capital account crisis when markets anticipate that exchange rate or debt service sustainability will not be maintained. The resultant collapse of the value of the currency will lead to a currency crisis. And the resultant failure to honor the debt servicing by banks and other financial institutions will increase financial vulnerability of the financial system leading to a banking or financial crisis.

Financial vulnerability is a complex and dynamic concept, and therefore, it is difficult to explain. At present, there is no universally accepted definition for financial vulnerability (Osterelo and De Haan, 2003). Following the definition of the financial stability of Houben et. al. (2004), financial vulnerability can be defined as a situation in the financial system in which it cannot allocate resources efficiently between activities and across time and cannot assess and manage financial risk, thereby weakening economic performance and wealth accumulation. At the same time, the system is not capable of absorbing shocks or vulnerability and thus cannot prevent adverse impacts. It is easy to measure the solvency of a financial institution but very difficult to measure the extent of vulnerability in a financial system.

There are several causes of financial vulnerability. The major reasons include: (i) fragility of the financial sector or system, (ii) weakness in prudential regulations and supervisions, (iii) spillover effects of weaknesses in the real sector such as real estate, mortgage and non-bank financial sectors, credit cards, and derivative markets, (iv) weaknesses in governance of financial institutions and their supervising authorities and risk management, (v) macroeconomic policy mismatch of financial and monetary policies, (vi) contagion effects, (vii) weaknesses in the international financial system or markets, (viii) sudden financial liberalization and (ix) weaknesses in legal infrastructure. Ideally, all such possible causes should be monitored. This paper will focus on monitoring the vulnerability of the financial sector as well as spillover effects of weaknesses in the real sector.

Contagion is a difficult concept to define. It can be defined as the transmission of a financial crisis to a country as a result of its real and financial interdependence with other countries that are already witnessing a financial crisis (Fratzscher, 2002). On many occasions these financial crisis does not happen solely in one country but instead has a contagion effect to other countries in the region as well. For example, the Latin American crisis of 1994 and the Asian crisis of 1997 affected many countries in the respective regions and sometimes across countries. Since July 2, 1997 following the devaluations of Thailand's currency, the local currencies of Malaysia, Indonesia, Philippines and later Singapore rapidly weakened. This crisis also adversely affected several non-Asian developing countries including Russia and Brazil due to the market perception of increased vulnerabilities in all emerging market economies.

The Asian crisis spawned a massive literature on the economics of crisis, in which numerous hypotheses have been advanced on the origin, development, and resolution of crises. There are however two main explanations for the Asian crisis. First generation models attributed the crisis to weak economic fundamentals such as unsustainable economic policies, vulnerability of the financial sector, and structural imbalances. This traces the crisis to inconsistency in policies such as monetization of persistently large budget deficits under a regime of fixed exchange rates (Krugman 1979). Second generation models, on the other hand, linked the crisis to the arbitrary shifts in market sentiments and emphasized the role of panics and self-fulfilling expectations (Pesenti and Tille 2000; Estanislao, Manzano, and Pasadilla 2000). 
The general understanding is that the financial crisis in Asia was multifaceted such as a combination of capital account, currency and banking crises. As Pesenti and Tille (2000) emphasize, the fundamental imbalances stressed by first generation models make a country vulnerable to shifts in investor sentiment; thereafter, once the crisis has begun, the second generation models explain the spiral and self-fulfilling nature of speculations.

The ongoing financial crisis started in September 2008 in USA is an outbreak of (i) gross financial irregularities(particularly of off-balance-sheet activities of financial institutions), (ii) the excesses in the housing and mortgage-backed securities markets, (iii) excessive risk taking, (iv) excess savings in emerging market economies with very low global interest rates causing speculation and asset market bubbles, (v) large global imbalances, and (vi) loose monetary policies in the U.S. since the 2002 recession, among others. The excess savings in emerging market economies, particularly in Asia was termed one of the major causes to the ongoing crisis. Asia's excess savings invested in advanced economies at a low interest rate facilitate overspending by advanced economies' consumer.

\section{Proposed Vulnerability Detection and Remedial Policy Formulation System}

Monitoring the soundness of the financial sectors in countries is the backbone of crisis prevention and an extremely challenging task. As stated earlier, it is easy to measure solvency of a financial institution but very difficult to measure the vulnerability of a financial system. Regular monitoring of the financial markets allows the early detection of significant fragilities within the financial system that may destabilize the sector. This also involves discovery of potential disturbances emerging from outside the banking system. Early detection and timely recognition of financial vulnerability will allow policymakers to trigger preemptive policy measures, aid financial supervisors to formulate and implement corrective measures, and allow businesses to adjust their business strategies. In this regard, it is imperative for a country to develop an appropriate system for early detection of any vulnerability in the financial system.

Monitoring can be carried out by different groups/sectors-markets, firms, consumers, policymakers, regional and international financial institutions, supervisory groupings, peer groups and countries with strong trade or economic links - with each level having differing approaches and objectives. However, for monitoring to be effective, it must not only be correct but it must be implemented properly. Monitoring domestic markets and institutions as well as implementing stability oriented policies should be undertaken by the countries themselves and should not be left to multilateral organizations, regional and international financial institutions. Ideally, high frequency monitoring should be performed by a high level monitoring committee with representations from central banks, the ministry of finance and other relevant ministries and supervisory authorities.

The proposed system outlines a process for identifying and compiling a set of leading MPIs, and methods for macroprudential analysis that will serve as flexible tools for analyzing and interpreting fluctuations in MPIs and translating underlying information to measure the magnitude and nature of vulnerability (or strength) and remedial policy implications for addressing vulnerability. The system involves the following steps:

(i) identification and compilation of leading indicators to represent key sectors of the domestic economy, such as Money, Credit and Interest Rates, Banking, Public Finance, External Debt and International Flows. Trade and International Reserves, Stock Market and Business Tendency Survey for Corporate Sector (some indicators 
for the external sector or global economy as well as those of major trading partners could also be included)

(ii) estimation of benchmark or threshold values for each indicator;

(iii) use of a signaling method for vulnerability assessment;

(iv) trend analysis and/or stress testing for indicators giving warning signals; and

(v) policy analysis for remedial policy recommendations to address vulnerabilities.

This system will serve as a basis for any preventive and remedial measures to address detected weaknesses in the economy and the financial system. A graphic representation of the framework is shown in Figure 1. Each of the above steps is explained in detail below. This high frequency of monitoring should be done fortnightly or monthly.

\section{Identification and Compilation of an Appropriate Set of Macroprudential/ Financial Soundness Indicators}

The availability of accurate and timely information is very important as demonstrated by the recent financial crisis in Asia, which highlighted the informational gaps in the affected economies. To illustrate, the build-up of currency and maturity mismatches, which had been the core among the weakness of several financial systems in Asia, was masked initially by the high economic growth rates, manageable inflation, and heady capital inflows. This lack of transparency contributed to the vulnerability because in a world of global capital flows, crises can arise if information surprises cause market participants to sharply change their expectations. In contrast, transparency and a continual flow of market information can help avoid panics and "creditor-grab" behavior. The lack of data and weak rules of disclosure, at that time, had hindered efforts to undertake economic and financial monitoring. 
Figure 1: A Macroprudential Analysis and Remedial Policy Formulation Quantitative System for High Frequency Monitoring of Vulnerabilty

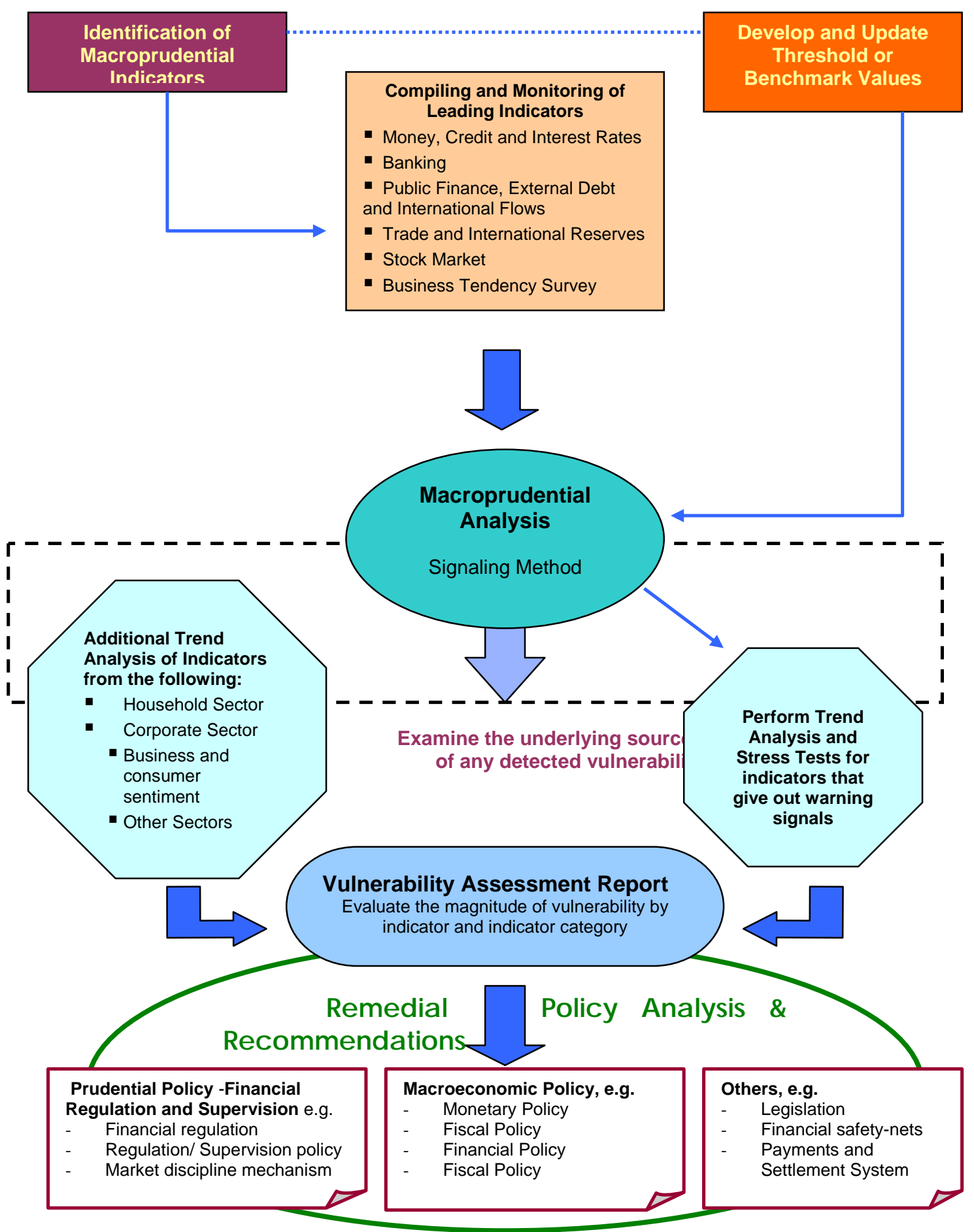


In recent years, particularly since the crisis, there are several studies proposing crisis monitoring indicators or early warning indicators that could be used to monitor the vulnerability of an economy. Bhattacharyay (2004) reviewed developments in the identification, compilation, analysis and interpretation of MPIs /FSIs. For many developing countries, it is quite difficult to estimate the crisis monitoring indicators due to the lack of timely and appropriate data. The majorities of official statistics is available after considerable time lag and are not very useful in estimating early warning indicators.

Compilation and analysis of MPIs are important components in theeconomic and financial sector monitoring activity. MPIs are a broad set of indicators that reflect the vulnerability of the financial and real economic system to shocks. MPIs include macroeconomic variables, such as inflation, asset prices, and interest rates in the economy and aggregated microprudential indicators, such as capital adequacy, asset quality, commodity price risk, and sovereign yield spread.

The development of MPIs is rather recent. The tools that are utilized to quantify and qualify the soundness and vulnerabilities of the financial system are varied and can potentially be made as complex or sophisticated as needed. Macroprudential analysis is a technique that uses information from MPIs to assess and monitor the strength and vulnerabilities of the financial system. Depending on the complexity, the operation of a monitoring system demands resources and technical expertise. The more sophisticated the system, the more costly it is to monitor and conduct macroprudential analysis. MPIs encompass FSIs and other relevant information that can provide a broad picture of a country's economic and financial condition such as the status of the institutional and regulatory frameworks, and compliance with international standards (Sundararajan et al. 2002). FSIs are a special subset of MPIs that specifically monitor the health and soundness of financial institutions and markets, and their corporate and household counterparts.

The effectiveness of the monitoring system should be evaluated according to the purpose with which they are designed. For instance, MPI analysis should be evaluated on how well it can track the vulnerability of a financial system as well as how it can effectively disseminate information to economic agents in the pursuit of better disclosure. Early warning systems can be evaluated on their record in predicting a crisis. Despite the increasing interest in more complex techniques employed in deploying monitoring and early warning systems (see Berg and Patillo 1999b for a review), it should be keptin mind that there are at least two aspects in monitoring: technical identification and interpretation of the indicators. It is thus important not only to define the purposes to which the indicators are to be used but also the analytical framework within which they are to be interpreted.

Given that financial and currency crises are complex phenomena, the identified set of MPIs should be comprehensive in nature. In this light, the MPIs need not be limited only to banking and financial statistics but have to take into account the general macroeconomy as well as the corporate and household sectors. In this manner, a more comprehensive assessment of the condition and health of the economy and financial systems can be conducted. At the same time identification of MPIs should be a dynamic process depending on the emerging vulnerability in certain sectors of the economy, such as emerging vulnerability in the insurance sector and credit card and consumer loans businesses.

Maintaining a wide set of indicators, however, has a downside -- collecting and monitoring a multiplicity of variables can be a daunting task, and can ultimately entail large costs. However, these costs can be reduced if it is possible to identify, from among the many different indicators, 
a manageable subset of core indicators, which can effectively give signals of vulnerability to a crisis. To illustrate, one of the criteria for choosing a core set of variables is whether the indicators are leading or coincident. Identifying a core set of indicators is not an easy task and work in this area, like the IMF system of MPI is still considered a work in progress. For work on MPIs to be fruitful, it has to be harmonious with the existing monitoring system of the country, taking into account the data constraints faced by the different countries. Different structures, levels of economic development and degrees of financial sophistication imply that different sets of MPIs are relevant to specific countries.

Ideally, the set of monitoring indicators should include appropriate FSIs in terms of liquidity, credit, market risks and banking health/soundless and other MPIs on macroeconomic vulnerability which may have spillover effects on the financial sector.

Under a regional technical assistance project, Asian Development Bank (ADB) conducted an inception workshop in April 2000 with the participating countries, which included Fiji; Indonesia; Philippines; Thailand; Taipei, China; and Viet Nam, and, in consultation with representatives from IMF, BIS, Deutsche Bundesbank, Frankfurt, Bank of Japan, Bank of Korea, Australian Bureau of Statistics, United Nation ESCAP. A set of 67 commonly agreed MPIs were identified during the workshop, belonging to the following groups of indicators, (i) External Debt and Financial Flows (8 indicators); (ii) Money and Credit (17 indicators); (iii) Banking (14 indicators); (iv) Interest Rates (12 indicators); (v) Stock Markets and Bonds (9 indicators); (vi) Trade Exchange and International Reserves (10 indicators); (vii) Business Survey Data (9 indicators): mainly Manufacturing but also Construction, Retail, and Wholesale Trade and Services. Bhattacharyay (2001) discussed the above commonly agreed indicators in detail. A list of the ADB commonly agreed indicators is given in Appendix 1.

Following the selection of the commonly agreed indicators, an attempt was made to identify a core set of 22 leading indicators that could give early warning signals of vulnerability of financial markets, based on graphical analysis of the series of MPIs compiled by countries. Bhattacharyay and Nerb (2002) identified a core set of leading indicators, based on trend analysis of the 67 commonly agreed MPIs compiled by selected crisis-affected Asian countries under the aforementioned ADB-supported project. Indicators that exhibited conspicuous behavior prior to 1997 Asian financial crisis were selected (Appendix 2). This core set of leading MPIs that gave warning signals or had large fluctuations prior to a crisis were selected as leading indicators. In cases where a clear lead could not be detected, it was labeled as coincident/leading. Further details on this method can be found in Bhattacharyay and Nerb (2002).

The International Monetary Fund (IMF) has been actively involved in the development of MPIs/FSIs. IMF (2001a) proposed a broad array of MPIs that could give a comprehensive assessment of the financial system and subsequently a core set of FSIs (Sundararajan et al. 2002) that are more useful and convenient for periodic monitoring. These aggregated MPIs mainly adopt the CAMELS framework, which is comprised of six groups of indicators reflecting the health of financial institutions: capital adequacy, asset quality, management soundness, earnings, liquidity, and sensitivity to market risk. The final set of IMF core and encouraged indicators are available in Compilation Guide on FSI (IMF, 2004) which provide guidance on the concepts and definitions, sources and techniques, for their compilation and dissemination.

One of the main objectives of identifying a core set of leading indicators is to identify indicators that appear to be particularly promising for financial and economic monitoring, and which therefore should be included in a core list of indicators. Although a broad and exhaustive set of 
indicators could potentially give a more complete assessment, they can be costly to compile and unwieldy to maintain. For the purpose of periodic high frequency monitoring, a separate core set of MPIs of manageable size should be kept and updated regularly.

As indicated earlier, one criterion for inclusion in the core set of MPIs is early warning capacity. Hence, the MPI should be a leading indicator or at the very least, a coincident one. A MPI is a leading indicator if it sends early vulnerability signals and coincident if it signals simultaneously with vulnerability. For a short-term monitoring system, however, only indicators that are available on a monthly or quarterly (at least) basis can be useful. Unfortunately, not all countries are able to fulfill this requirement.

The data series for many developing countries are not very long and are not always complete over the whole time span. Many aggregated microprudential indicators are not yet available for many countries. This prevents the use of formal statistical methods like regression or factor analysis to identify the best candidates for a harmonized set of core MPIs. Nevertheless, this should be done in a later stage to identify the exact informational content of those series and to estimate the joint impact of different subsets of indicators for explaining and forecasting banking and currency crises.

The selection of core indicators should be harmonious with the existing monitoring system of the country and take into account the data constraints. A country should adopt an appropriate core set of indicators from ADB commonly agreed, IMF FSIs and other suitable indicators from crisisrelated studies. The selected indicators should be tailor-made for a country's specific characteristics, based on economic rationale and early warning capability and available for high frequency monitoring.

\section{Macroprudential Indicators: Analysis and Interpretation of MPIs}

Some progress has been made in identifying and compiling accurate and timely MPIs. The focus is now beginning to shift towards the development of techniques for the proper analyses and interpretation of data. Work on the analysis of MPIs and their interpretation is still recent and there is no consensus on the best analytic framework for determining the vulnerability of a financial system or a set of widely accepted MPIs. It needs be appreciated that the task of macroprudential analysis or the framework for identifying, analyzing, and interpreting MPIs is still a work-in-progress.

Various international and regional financial institutions, such as the IMF, Bank for International Settlements (BIS), and European Central Bank (ECB) as well as private institutions are still in the process of developing or testing different systems. In general, most macroprudential analysis is based on trend analysis and the identifications of large movements in the level of selected MPIs (without comparing with a threshold and critical values) for assessing risk/vulnerability leading to a crisis. These methods usually analyze a composite of macroeconomic and microeconomic prudential indicators. Most macroprudential analysis is judgmental together with other tools of macroprudential assessment. As such, there is no standard system for macroprudential analysis at present. Yet, as the experience of the Asian crisis shows, a systematic monitoring of the financial and economic systems is an important element in crisis prevention strategies.

There are several studies that are based on empirical analysis on countries that have been affected by crisis in past. The identified indicators have been found useful to predict the past 
crisis based with a high probability on past time-series data. However, it is not sure whether the same indicators would be able to predict future crisis with a reasonable degree of accuracy. At the same time, it is not possible to predict the timing of the start of the crisis. Another major problem in crisis-monitoring activities is wrongly predicting vulnerability that may cause a confidence problem in the market and thus may initiate a crisis. Therefore, it is not clear if the use of quantitative models for predicting probabilities of a crisis is useful.

Another major obstacle is to come up with an appropriate threshold a value or benchmark beyond which signifies vulnerability for each indicator. When the level of an indicator is large (or small), the vulnerability is high. However, there are no benchmarks on how large should be the magnitude of the indicator as no norms are available and there is an urgent need to develop benchmarks.

Macroprudential analysis should not be limited to quantitative indicators alone. Qualitative information is very important. This includes credit ratings by international credit rating agencies

At present, several developing countries conduct macroprudential analysis as well as many developed countries based on the trends of available MPIs, noting any large or significant movements and on the basis of expert judgment. Any particular kind of risk, such as liquidity risk has to be assessed based on a set of related indicators and proper judgment has to be used to detect any significant vulnerability

There are several existing methods that use MPIs to monitor economic and financial vulnerability. The major methods include: (i) trend analysis, which detects vulnerability when there are major fluctuations in a particular indicator; (ii) stress-testing, which gauges vulnerability by estimating the impact of a range of future shocks to the system on certain variables; and (iii) Early Warning Signal (EWS) models, which estimate the probability of a crisis occurring through quantitative or econometric techniques. A country should adopt an appropriate framework tailor-made for its specific characteristics using all or some of the above methods for macroprudetnial analysis. The brief explanations of the above methods are presented in the following sections.

\section{Trend Analysis}

Trend analysis entails looking at the movement of data over a given period of time and taking note of deviations from an observed pattern or large fluctuations. The major drawback of this technique lies in the interpretation of notable data deviation. It would not be immediately apparent if this signifies stress in the system or simply a result of structural breaks due to changes in regulations or regimes. As it is somewhat subjective,the reliability of trend analysis depends largely on the skill and experience of the technical staff. It is currently the most common method used because it is cost-effective, transparent, and simple enough to be easily grasped by policymakers.

\section{Stress Testing}

Stress testing is a multi-step simulation process or method of examining key risks, vulnerabilities and exposures in an economic or financial system It is designed to evaluate vulnerability against major changes or shocks in the system. It provides information on the behavior of a system under exceptional but plausible shocks or the impact of a range of future shocks to certain variables of the a system. It estimates changes in the MPI due to a specific type or set of shocks that are based on historical or hypothetical (but plausible) circumstances, i.e., the impact of an economic slowdown on the level of nonperforming loans. Stress tests, 
however, do not estimate the probability of the shock occurring. Stress testing is regularly used in the Financial Sector Assessment Program (FSAP) of the IMF/ World Bank (Sundararajan et al. 2002 and IMF and World Bank, 2003). IMF (2001b) provided further details on stress testing. Blascke et. al. (2001) presented an overview of issues, methodologies and FSAP experience regarding stress tests.

The stress testing involves the following steps:

(i) Identifying major vulnerabilities, risks and exposure or potential sources of shocks, such as interest rates, exchange rates, credits, equity prices, liquidity, inter-bank contagion, real estates, key exports, key commodities- in terms of fall in prices and volatility;

(ii) Defining coverage and identifying data: all systemically relevant institutions and exposures;

(iii) Calibrating shocks and scenarios: establishing key linkages between the financial system and the real economy- a formal macroeconomic model or macro-simulation models.

(iv) Selecting and implementing methodology-crunching numbers: translating the various output of the macroeconomic model into financial institutions balance sheet and income statements.

(v) Interpreting and using the results: policy makers compare the impact of a common set of shocks on different institutions. For interpreting stress tests, one should consider the limits and assumptions on which they are built ( Jones et. al., 2004 and Cihak, 2003)

Stress test has some limitations. Like trend analysis, it also relies on the judgment and experience of monitoring staff to identify the proper set of scenarios to be used in the test and to interpret the result correctly-only first order approximation to the true potential loss exposure. It does not capture the full range and interaction of risk exposure (such as operational and legal risk). It should be compared with other measure of risk exposure such as empirical analysis of macro-prudential/ financial soundless indicators. Moreover, it is complicated and timeconsuming and hence difficult to undertake frequently, which makes it an inappropriate tool for high frequency monitoring. Furthermore it is a resource intensive process in terms of technical expertise, data requirement and budget.

\section{Early Warning Signal (EWS) Models}

Early warning signal models were developed to estimate the probability of a crisis occurring based on the movement of MPIs. Early warning models based on MPI are relatively new approaches introduced and discussed in academic and policy circles. Some of the more recent work in this area are Kaminsky and Reinhart (1999); Kaminsky, Lizondo, and Reinhart (1998); Goldstein, Kaminsky, and Reinhart (2000); Berg and Patillo (1999); Edison (2000); and Berg et al. (2004). This is used in the private financial institutions like Goldman Sachs and Credit Suisse First Boston (Berg and Petillo 2004).

EWS models estimates the probability of a crisis occurring through quantitative or econometric techniques based on the movement of MPI's. It is a sound and objective methods for early warning.

There are generally two types of EWS models, one that is based on a composite of leading indicators and another that makes use of probit/logit models. The composite indicator model 
creates a composite figure using the number of "warning signals" obtained from a set of MPIs and directly tying it with a probability of a crisis. A warning signal is emitted whenever an indicator is theoretically associated to a crisis breaches a critical threshold (Kaminsky, Lizondo, and Reinhart, 1998). Probit or logit models, on the other hand, compute a probability of a crisis occurring based on changes in behavior of indicators prior to crises (Berg et al. 1999). There are separate EWS models for currency and banking crises. No common model is available for predicting any types of crisis.

However, the predictive accuracy of the existing early warning models are limited as noted in the existing literature (Berg and Patillo 2000). The financial market is highly complex and the composite index technique used in most EWS models is too simplistic to capture the nuances of the sector. Indices are also potentially misleading because in the process of producing a single figure to capture the effect of a set of indicators, positive and negative signals of individual components may cancel each other out (Evans et al. 2000). The quantitative models such as probit and logit, on the other hand, have mixed performance in detecting a crisis or financial vulnerability especially in the context of out-of-sample forecasting. EWS are also complicated, expensive, and nontransparent, and require extensive time-series data, which is not always available for some countries and certain variables (Berg, Borenzstein and Petillo, 2004).

Also, countries that did not experience a crisis, can not build a EWS model using its data series. Most countries do not compile IMF FSIs and a few countries have started to compile FSIs very recently. EWS models are, therefore, not suitable for high frequency monitoring.

The choice of approach in analyzing and interpreting MPIs would depend on several factors, such as the desired level of accuracy, cost, timeliness, purpose and nature of policy action expected, and technical capacity of monitoring personnel and policy makers. Clearly, there are trade-offs among these factors. For instance, simple methods can generate indicators faster than more complicated ones but it may only be adequate if the goal is simply to alert the authorities on possible vulnerabilities in the system. It may not be able to generate specific probabilities to the occurrence of crises that more sophisticated techniques can provide.

A fundamental issue to consider is whether crises are predictable which, as the literature suggest, is still subject to qualifications. However, using MPIs to predict the probability of an impending crisis using a EWS model may be time-consuming and will be of limited use if it arrives after the onset of the crisis or with insufficient time left to avert it. At the same time, these kinds of models, so far, have not performed well in predicting the occurrence of a crisis, especially for out-of-sample data (Berg, Borenzstein and Petillo, 2004). The choice of the model is also determined by the technical capacity of the agents maintaining the models. The cost and technical capacity required to regularly undertake MPI analysis also vary with the complexity of the technique, with more sophisticated methods requiring more resources and highly trained staff. In the end, the trade off between sophistication/complexity and accuracy is cost.

In view of the above, quantitative EWS models can not be used alone to monitor financial vulnerability leading to a crisis. Trend analysis, stress testing and other traditional surveillance methods should be used together with EWS models for macroprudential analysis. 


\section{A Proposed Quantitative Monitoring System}

Now, a proposed quantitative Monitoring system using 30 selected MPIs is presented below.

\section{Identification and Compilation of MPIs}

The framework proposed here could be the initial model for use in MPI analysis for any country. It makes use of 30 indicators that were selected from ADBs commonly agreed MPIs, IMF MPIs/FSIs, Goldstein, Kaminsky and Reinhart (2000), and Reinhart, Kaminsky and Lizondo (1998). The selection is based on economic rationale as well as findings of empirical studies on currency and banking crises involving various countries and regions. The MPI should preferably be available on a high-frequency basis (i.e. monthly). The MPI's and the economic rationale for their inclusion and their characteristics (in terms of nature of detecting or predicting vulnerability) can be found in Table 6 . An indicator is considereda leading indicator if it signals before vulnerability sets in and coincident if it signals during periods of vulnerability.

These MPIs can be grouped into six broad categories, namely (i) Money, Credit and Interest Rate, (ii) Banking, (iii) Public Finance, External Debt and International Flows, (iv) Trade and International Reserve, (v) Stock Market and (vi) Business Tendency Survey. Some of the leading indicators need to be transformed to ensure that they are stationary and free from seasonal effects first. The level form should be adopted if the indicator does not display any trending or seasonal behavior. The list of leading MPI's and the economic and financial rationales for their inclusion and their characteristic (in terms of nature of detecting or predicting vulnerability) can be found in Table 1.

These MPIs should be compiled and updated regularly. Identification of MPIs is a dynamic process. Therefore, the list of MPIs should be updated on a regular basis depending on the emerging areas of concern in the economy and the financial sector.

\section{Macroprudential/Financial Soundness Analysis and Determination of Threshold Values}

These macroprudential/financial soundness indicators are compared to a set of country-specific benchmark figures or threshold values. A vulnerability signal is flashed when an observed outcome of a MPI crosses its threshold value. It indicates a departure or deviation from normal behavior in an MPI. For example, an abnormally large increase in real estate loan may signal high vulnerability in the banking or financial sector, which might lead to a banking crisis. MPIs should be monitored on a high frequency basis to detect any significant vulnerability or weakness in the economy in general, and the financial sector in particular, which could make a country susceptible to a currency or financial crisis. The higher the number of indicators flashing signals at any given period indicates higher vulnerability. 
Table 1: List of Leading MPIs, Economic and Financial Rationale for Selection, and Predictive Characteristics

\begin{tabular}{|c|c|c|}
\hline & Rationale & Characteristic \\
\hline \multicolumn{3}{|l|}{ Money, Credit and Interest Rates } \\
\hline M2, Growth, y-o-y & $\begin{array}{l}\text { High growth rate of this indicator might indicate } \\
\text { excess liquidity that may fuel speculative attacks on } \\
\text { the currency and lead to a crisis. }\end{array}$ & Coincident/leading \\
\hline \begin{tabular}{|l} 
Domestic Credit \\
- \\
Growth, y-o-y \\
Ratio to GDP
\end{tabular} & $\begin{array}{l}\text { Considered as an indicator of a monetary policy } \\
\text { stance w/c is incompatible with the currency peg. } \\
\text { Very high growth rates of domestic credit may serve } \\
\text { as a crude indicator of the fragility of the banking } \\
\text { system. Its ratio to GDP usually rises in the early } \\
\text { phase of the banking crisis. It may be that as the } \\
\text { crisis unfolds, the central bank may be pumping } \\
\text { money to the banks to alleviate their financial } \\
\text { situation. }\end{array}$ & Coincident/leading \\
\hline $\begin{array}{l}\text { Real Money Market Rate/Inter-Bank } \\
\text { Rate }\end{array}$ & $\begin{array}{l}\text { A sharp increase in this rate signals a tight liquidity } \\
\text { situation in the banking sector, which can possibly } \\
\text { lead to solvency problems }\end{array}$ & Leading \\
\hline Lending Deposit rate spread & $\begin{array}{l}\text { An increase above a threshold level possibly reflects } \\
\text { deterioration in credit risk, as banks are unwilling to } \\
\text { lend. }\end{array}$ & \\
\hline \multicolumn{3}{|l|}{ Banking } \\
\hline $\begin{array}{lr}\text { Net } & \text { Bank Profits } \\
\text { - } & \text { Return on Assets } \\
\text { - } & \text { Return on Equity }\end{array}$ & $\begin{array}{l}\text { Unusually high profitability may be a sign of } \\
\text { excessive risk-taking or imperfectly competitive } \\
\text { financial sectors, but too low profits can indicate } \\
\text { deterioration in credit quality or intense competition }\end{array}$ & Leading \\
\hline Total Bank Loans to Total Deposits & $\begin{array}{l}\text { A high ratio may indicate stress in the banking } \\
\text { system and a low level of liquidity to respond to } \\
\text { shocks }\end{array}$ & Leading \\
\hline Credit to Private Sector, Ratio to GDP & $\begin{array}{l}\text { Over-investment of the private sector could lead to a } \\
\text { deterioration in the quality of credit portfolios of the } \\
\text { banking sector }\end{array}$ & Coincident/leading \\
\hline $\begin{array}{l}\text { Central Bank Credit to the Banking } \\
\text { System }\end{array}$ & $\begin{array}{l}\text { A large increase in central bank credit to banks and } \\
\text { other financial institutions often reflects severe } \\
\text { liquidity or solvency problems in the financial sector }\end{array}$ & Coincident/leading \\
\hline 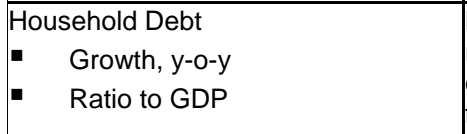 & $\begin{array}{l}\text { Households are more sensitive to changes in interest } \\
\text { rates, income and asset prices. A too high proportion } \\
\text { of loans to this sector may pose additional risk to the } \\
\text { financial sector. }\end{array}$ & Coincident/leading \\
\hline $\begin{array}{l}\text { Real Estate Loans (Ratio to Total } \\
\text { Loans) }\end{array}$ & $\begin{array}{l}\text { In the past, many financial crises have been caused } \\
\text { or amplified by downturns in particular sectors of the } \\
\text { economy spilling over into the financial system. This } \\
\text { has often been the case for concentration in real } \\
\text { estate, which can be subject to severe boom and } \\
\text { bust price cycles. }\end{array}$ & Leading \\
\hline $\begin{array}{l}\text { Non-performing Loans (Ratio to Total } \\
\text { Loans) }\end{array}$ & $\begin{array}{l}\text { High levels of NPLs indicate deteriorating asset } \\
\text { quality of the financial system. }\end{array}$ & Coincident/lagging \\
\hline \begin{tabular}{|l|} 
Liquid Assets to Short-term Liabilities \\
\end{tabular} & $\begin{array}{l}\text { This indicator measures the banking system's } \\
\text { capability to meet short-term debt obligations. A too } \\
\text { low ratio may result to liquidity problems if debtors } \\
\text { decide to pull out their funds. }\end{array}$ & Coincident/leading \\
\hline \multicolumn{3}{|l|}{$\begin{array}{l}\text { Public Finance, External Debt and } \\
\text { Financial Flows }\end{array}$} \\
\hline Overall budget deficit to GDP & $\begin{array}{l}\text { Large fiscal deficits could lead to a worsening of the } \\
\text { current account position, which could in turn put } \\
\text { pressure on the exchange rate }\end{array}$ & Coincident/Leading \\
\hline $\begin{array}{l}\text { Short-Term International Borrowing or } \\
\text { External debt with maturities one year } \\
\text { or less }\end{array}$ & $\begin{array}{l}\text { A large increase in short-term debt indicates } \\
\text { vulnerability in the solvency of the country. }\end{array}$ & Leading \\
\hline
\end{tabular}




\begin{tabular}{|c|c|c|}
\hline \multicolumn{3}{|l|}{ Trade and International Reserves } \\
\hline Trade Balance to GDP & $\begin{array}{l}\text { Deterioration in the trade balance could signal } \\
\text { declining international competitiveness. It also leads } \\
\text { to a worsening of the current account, which is often } \\
\text { associated with currency crisis. }\end{array}$ & Coincident/leading \\
\hline Real effective exchange rate & $\begin{array}{l}\text { If real appreciation of a currency is not backed by } \\
\text { corresponding productivity gains in the real } \\
\text { economy, this implies a loss of international } \\
\text { competitiveness which can be a possible source of } \\
\text { vulnerability. Also, real appreciation of a currency } \\
\text { that occurs in the context of a large current deficit is } \\
\text { a source of increased vulnerability. }\end{array}$ & Coincident/leading \\
\hline $\begin{array}{ll}\text { International Reserves } \\
\text { - } \quad \text { Growth, y-o-y } \\
\text { In months of imports }\end{array}$ & $\begin{array}{l}\text { A low and declining amount of international reserves } \\
\text { signals possible problems for the country to meet } \\
\text { international payment requirements and the } \\
\text { economy's import demands. }\end{array}$ & Leading \\
\hline \multicolumn{3}{|l|}{ Stock Market } \\
\hline $\begin{array}{l}\text { Composite Stock Price Index } \\
(1997=100)\end{array}$ & $\begin{array}{l}\text { A sharp decline in stock prices may signal adverse } \\
\text { market perception of the health of the stock market. } \\
\text { Declining asset prices usually precedes financial } \\
\text { crises. }\end{array}$ & Leading \\
\hline Stock Price Earnings Ratio & $\begin{array}{l}\text { A high and increasing stock price earnings ratio may } \\
\text { signal asset inflation, which is unsustainable in the } \\
\text { medium term }\end{array}$ & Leading \\
\hline \multicolumn{3}{|l|}{$\begin{array}{l}\text { Business Expectation Survey } \\
\text { Indicators }\end{array}$} \\
\hline $\begin{array}{l}\text { Current Business Situation } \\
\text { Expected Business Situation (next } 6 \\
\text { months) } \\
\text { Stock of Finished Products } \\
\quad \text { Industry } \\
\quad \text { Wholesale and retail trade } \\
\text { Employment (present situation)-here } \\
\text { next quarter } \\
\text { Financial Situation (present situation) }\end{array}$ & $\begin{array}{l}\text { BTS are able to capture current and future } \\
\text { profitability trends. Answers on the current business } \\
\text { situation as well as on the expected business trend } \\
\text { in the next three to six months reflect the perceived } \\
\text { profit assessment of managers which are not only } \\
\text { important for the real economy but also has } \\
\text { implications for the financial sector. }\end{array}$ & Coincident/leading \\
\hline
\end{tabular}

Alternative methods to construct benchmarks/threshold values include use of: (i) historical average of MPI for countries with previous crisis experience, wherein an average around the period of crisis or periods immediately prior to the crisis could be used; (ii) prudential threshold values used by bank supervisory authorities or international financial institutions; (iii) average MPI of a similar country with a strong financial system; (iv) using econometric methods such as EWS models (v) average MPI of a similar country with a strong financial system and (vi) historical trigger points that caused a currency crisis. A possible and safer alternative would be to use more than one threshold value for one indicator.

Ideally, econometric techniques like the EWS signaling approach pioneered by Kaminsky, Lizondo, and Reinhart (1998) should be used to determine benchmarks figures/threshold values because these provide the most objective method in determining threshold values. However, this type of econometric technique requires long time series of high-frequency data and can be used only for countries that have a history of currency or banking crisis. However, this methodology of determining threshold values is not based on transparent or economic or financial criteria and is considered as a black box by policy makers. At the same time, the performance of these models in predicting future crisis accurately is poor. 
In the proposed system, country-specific threshold values are estimated for each MPI. These MPIs are compared to a set of country-specific threshold values on a monthly or quarterly basis. A vulnerability signal is flashed when an observed outcome of an indicator crosses its threshold value. The higher the number of indicators flashing out signals at any given period indicates heightened vulnerability.

The proposed framework deviates from the method introduced by Kaminsky, Lizondo, and Reinhart (1998) model by focusing on determining the magnitude of vulnerability in the system and identifying specific area(s) of concentration instead of estimating the probability of a crisis event. The proposed framework will also employ trend analysis to examine the actual values of those indicators that had significant jumps in the number of signals flashed or which had persistently flashed signals throughout the surveillance period. This will confirm if the signals given is unwarranted, stems from institutional or structural changes, or requires serious attention so that appropriate policy action and other corrective measures may be suggested to reverse or mitigate the vulnerability detected.

Trend analysis of actual indicators of increasing vulnerability signals are also performed to reassess the extent of vulnerability and to provide a basis for any suggested policy actions. Depending on the magnitude of vulnerability as exhibited by one or more indicates, stress tests need to be perfumed for the areas of potential risk. For example, stress test could be performed for assessing shocks and risks in interest rate, commodity price (oil price), exchange rate, equity prices, credit and liquidity in banks and financial institutions. There is a need to analyze the underlying source of chronic vulnerability. Trend analysis of related indicators need to be performed. Appropriate policy actions are then formulated in order to address the vulnerability.

This method is selected because it can be used by most developing countries, even those that do not have long-term data or crisis experience. Threshold values used here are based mostly on the average of crisis affected countries using quarterly data between 1995 and 1997. In some instances, the average of a country with specific crisis experience (i.e. Korea for household credit) or an international standard (i.e. EU Stability and Growth Pact rule for budget deficit) was used. A vulnerability signal is emitted when actual values breach the threshold value.

It should be noted that macroprudential analysis under this framework should focus not only one symptoms-whether the MPI is above or below the threshold value - but on the underlying sources of chronic vulnerability. Therefore, trend analysis of related indicators with causal relationship with the concerned MPIs flashing vulnerability signals should be undertaken to assess the underlying sources of vulnerability. Appropriate policy actions are then suggested in order to address the vulnerability as indicated by the flashed signals.

\section{Policy Analysis and Recommendations}

Continuous monitoring of financial system stability with respect to structural, institutional and macroeconomic aspects is not only crucial in detecting and preventing financial crisis but also in ensuring strong macroeconomic performance and effective implementation of monetary policy at the national level. 
The results of the vulnerability assessment will be the basis for the policy recommendations. The kind of warning signals given provides a clue on the appropriate policy actions needed to address existing or potential weaknesses. Further trend analysis of underlying factors causing warning signals for a particular or a group of indicators will assist in policy recommendations.

In general, policy recommendations can be categorized into (i) financial regulation and supervision policies, (ii) macroeconomic policies, such as fiscal, monetary and financial policies; and (iii) policies governing financial infrastructure, such as legislation, payments and settlements system and financial safety nets (See Figure 1). Ideally, alternative policy actions should be recommended for addressing specific vulnerabilities. Some examples of policy recommendations are given below.

Typically, financial systems are exposed to credit risk, liquidity risk and market risk (which includes interest rate, exchange rate, and equity price risks). For assessing the soundness of the financial sector, the results of signaling methods should be interpreted in terms of credit, liquidity, and market risks. For example, addressing the credit risk of a country arising out of excessive growth of credit to GDP ratio, loan to deposit ratio and money supply may require several policy actions such as restrictions on further lending to certain over heated sectors, such as real estate and consumer finance and the ratio of each sector lending to total lending share capped at $10 \%$. There is also a need for a closer monitoring of credit policy and credit appraisal system. Sharp increases in credit card default may necessitate the imposition of higher minimum salary requirement for credit card holder and setting up a credit card information bureau to avoid multiple cardholding

For the fiscal sector, high levels of public debt, fiscal deficit and government consumption compared to the GDP of a country with narrow export base could be unsustainable in the case of an economic downturn, poor budgetary performance, orrise in real interest rates due to a world economic recovery. Effective fiscal management through better tax collection and public expenditure management is required to reduce the debt burden and assure debt sustainability against sudden shocks.

There is also a time dimension to the range of possible policy recommendations. Policy recommendations can be categorized as short-, medium- and long-term in nature, in terms of the time required for their effective implementation. Usually, short- and medium-term policies are recommended for high frequency monitoring.

Producing effective policy actions for recommendation relies heavily on the timeliness and reliability of available information. It is therefore important to monitor how near the actual figures are to their threshold value rather than wait for them to breach the threshold in order to have enough time to implement pre-emptive measures and avoid the crippling cost of a full-blown crisis.

\section{An Empirical Illustration}

An empirical illustration is given in this section to show how the proposed framework could be used to analyze MPIs using data from the Philippines in order to detect economic and financial vulnerability. It is based on $30 \mathrm{MPIs}$ that were selected based on economic rationale as well as findings from empirical studies.

As mentioned earlier, the surveillance should ideally be performed on a monthly basis. However, to show that this approach can still apply to countries with data limitations, quarterly 
data for the last three years (2002 to 2004) was used. For illustrative purposes, the data provided here is on an annual basis with quarterly performance for 2004. Threshold values were derived from regional averages of pre-crisis data (1995-1997) unless otherwise specified.

\section{Determination of Threshold Values}

Philippines-specific threshold values are estimated for each MPI. Threshold values used here are based mostly on the average of crisis affected Asian countries using quarterly data during 1995-1997. In some instances, the average of a country with specific crisis experience (i.e. Korea for household credit) or an international standard (i.e. EU Stability and Growth Pact rule for budget deficit) was used. This simple method is selected because it can be used by most developing countries, even those that do not have long-term data or prior crisis experience. Table 2 presents the methods or rationale for the computation methods for threshold values.

Only Korea has pre-crisis data on household debt among the crisis-affected countries. It is also the only one with extremely high levels of consumer debt. Korea's household debt was exacerbated by the excessive use of credit cards in the post-crisis years and culminated in the bankruptcy of many credit card companies in 2003 , which led to a weakening of the domestic economy as personal consumption plummeted. The threshold value is computed using the data over the years 2001 and 2002 which represents the period prior to the burst of the credit card or "plastic bubble".

Table 2: Methods of Determination of Threshold Values

\begin{tabular}{|c|c|c|}
\hline & $\begin{array}{l}\text { Data Source for } \\
\text { Threshold Values }\end{array}$ & Determination of Threshold Value \\
\hline \multicolumn{3}{|l|}{$\begin{array}{l}\text { Money, Credit and Interest } \\
\text { Rates }\end{array}$} \\
\hline M2, y-o-y growth & $\begin{array}{l}\text { Economic Intelligence } \\
\text { Unit, Bank of Korea }\end{array}$ & $\begin{array}{l}\text { Average of crisis affected countries from } \\
\text { 1Q1995 to 4Q1997 }\end{array}$ \\
\hline \multicolumn{3}{|l|}{ Domestic Credit } \\
\hline - Growth, y-o-y & $\mathrm{IFS}^{4}, \mathrm{ARIC}^{5}$ (for CPI) & $\begin{array}{l}\text { Average of crisis affected countries from } \\
\text { 1Q1995 to 4Q1997 } \\
\text { Note: Domestic credit was deflated using the } \\
\text { CPI prior to obtaining y-o-y growth rates }\end{array}$ \\
\hline - Ratio to GDP & $\begin{array}{l}\text { IFS, Bank Indonesia (for } \\
\text { GDP) }\end{array}$ & $\begin{array}{l}\text { Average of crisis affected countries from } \\
\text { 1Q1995 to 4Q1997 } \\
\text { Note: GDP is the sum of the current and } \\
\text { previous three quarters }\end{array}$ \\
\hline Real Money Market Rate & IFS, ARIC (for CPI) & $\begin{array}{l}\text { Average of crisis affected countries from } \\
\text { 1Q1995 to 4Q1997 } \\
\text { Note: This indicator was derived by } \\
\text { subtracting inflation (derived from CPI) from } \\
\text { the nominal money market rate }\end{array}$ \\
\hline Lending Deposit rate spread & $\begin{array}{l}\text { Bank Indonesia, Bank of } \\
\text { Thailand, Bangko } \\
\text { Sentral ng Pilipinas, } \\
\text { Bank Negara Malaysia, } \\
\text { IFS (for Korea) }\end{array}$ & $\begin{array}{l}\text { Average of crisis affected countries from } \\
\text { 1Q1995 to 4Q1997 }\end{array}$ \\
\hline
\end{tabular}

\footnotetext{
${ }^{4}$ International Financial Statistics Publication of IMF

${ }^{5}$ Asia Regional Information System website of ADB
} 


\begin{tabular}{|c|c|c|}
\hline $\begin{array}{l}\text { Additional: Differential between } \\
\text { Domestic and US real interest } \\
\text { rate }\end{array}$ & $\begin{array}{l}\text { Bank Indonesia, Bank of } \\
\text { Thailand, Bangko } \\
\text { Sentral ng Pilipinas, } \\
\text { Bank Negara Malaysia, } \\
\text { Board of Governors of } \\
\text { the Federal Reserve } \\
\text { System (for 90-dat } \\
\text { Treasury Bill), IFS (for } \\
\text { Korea) }\end{array}$ & $\begin{array}{l}\text { Average of crisis affected countries from } \\
\text { 1Q1995 to 4Q1997 }\end{array}$ \\
\hline \multicolumn{3}{|l|}{ Banking } \\
\hline Net Bank Profits & ARIC & $\begin{array}{l}\text { Average of crisis affected countries from } \\
\text { 1Q1995 to 4Q1997 }\end{array}$ \\
\hline - Return on Assets & ARIC & $\begin{array}{l}\text { Average of crisis affected countries from } \\
\text { 1Q1995 to 4Q1997 }\end{array}$ \\
\hline $\begin{array}{l}\text { Total Bank Loans to Total } \\
\text { Deposits }\end{array}$ & ARIC & $\begin{array}{l}\text { Average of crisis affected countries from } \\
\text { 1Q1995 to 4Q1997 }\end{array}$ \\
\hline $\begin{array}{l}\text { Credit to Private Sector, Ratio } \\
\text { to GDP }\end{array}$ & ARIC & $\begin{array}{l}\text { Average of crisis affected countries from } \\
\text { 1Q1995 to 4Q1997 } \\
\text { (Note: GDP is the sum of the current and } \\
\text { previous three quarters) }\end{array}$ \\
\hline $\begin{array}{l}\text { Central Bank Credit to the } \\
\text { Banking System, y-o-y growth }\end{array}$ & IFS, ARIC (for CPI) & $\begin{array}{l}\text { Average of crisis affected countries from } \\
\text { 1Q1995 to 4Q1997 } \\
\text { (Note: Central Bank Credit to the Banking } \\
\text { System was deflated using the CPI prior to } \\
\text { obtaining year-to-year growth rates.) }\end{array}$ \\
\hline \multicolumn{3}{|l|}{ Household Debt } \\
\hline - Growth, y-o-y & Bank of Korea & $\begin{array}{l}\text { Average for Korea between 1Q2001 and } \\
\text { 4Q2002 }\end{array}$ \\
\hline - Ratio to GDP & $\begin{array}{l}\text { Bank of Korea, IFS (for } \\
\text { GDP) }\end{array}$ & $\begin{array}{l}\text { Average for Korea between 1Q2001 and } \\
\text { 4Q2002 } \\
\text { (Note: Here GDP is the sum of the current } \\
\text { and previous three quarters.) }\end{array}$ \\
\hline $\begin{array}{l}\text { Real Estate Loans (Ratio to } \\
\text { Total Loans) }\end{array}$ & $\begin{array}{l}\text { IFS and websites of } \\
\text { Bank Indonesia, Bank } \\
\text { Negara Malaysia, } \\
\text { Bangko Sentral ng } \\
\text { Pilipinas }\end{array}$ & $\begin{array}{l}\text { Average of crisis affected countries from } \\
\text { 1Q1995 to 4Q1997 }\end{array}$ \\
\hline $\begin{array}{l}\text { Non-performing Loans (Ratio to } \\
\text { Total Loans) }\end{array}$ & $\begin{array}{l}\text { IFS and websites of } \\
\text { Bank Indonesia, Bank } \\
\text { Negara Malaysia, } \\
\text { Bangko Sentral ng } \\
\text { Pilipinas }\end{array}$ & $\begin{array}{l}\text { Average of crisis affected countries from } \\
\text { 1Q1995 to 4Q1997 }\end{array}$ \\
\hline \multicolumn{3}{|l|}{$\begin{array}{l}\text { Public Finance, Extemal Debt } \\
\text { and Financial Fows }\end{array}$} \\
\hline Overall budget deficit to GDP & ARIC & $\begin{array}{l}\text { Based on EU Stability and Growth } \\
\text { Pact(SGP) of } 1997 \text { (Rationale: Despite } \\
\text { existing controversies on the apparent } \\
\text { arbitrariness of the SGP reference value, the } \\
3 \% \text { ratio of government deficit to GDP can } \\
\text { be considered as an international standard.) }\end{array}$ \\
\hline $\begin{array}{l}\text { Short-Term International } \\
\text { Borrowing or External debt with } \\
\text { maturities one year or less }\end{array}$ & ARIC & $\begin{array}{l}\text { Average of crisis affected countries from } \\
\text { 1Q1995 to 4Q1997 }\end{array}$ \\
\hline
\end{tabular}




\begin{tabular}{|l|l|l|}
\hline $\begin{array}{l}\text { Trade and International } \\
\text { Reserves }\end{array}$ & IFS & \\
\hline Trade Balance to GDP & ARIC & $\begin{array}{l}\text { Average of crisis affected countries from } \\
\text { 1Q1995 to 4Q1997 }\end{array}$ \\
\hline $\begin{array}{l}\text { Nominal exchange rate (y-o-y } \\
\text { change) }\end{array}$ & IFS & $\begin{array}{l}\text { Average of crisis affected countries from } \\
\text { Aver to 4Q1997 }\end{array}$ \\
\hline International Reserves & $\begin{array}{l}\text { Average of crisis affected countries from } \\
\text { 1Q1995 to 2Q1997 } \\
\text { (Rationale: The last two quarters of 1997 } \\
\text { was left out because this period was } \\
\text { characterized by massive utilization of } \\
\text { reserves as countries struggled to defend } \\
\text { their currencies.) }\end{array}$ \\
\hline GIR in months of imports & ARIC & $\begin{array}{l}\text { Average of crisis affected countries from } \\
\text { 1Q1995 to 4Q1997 }\end{array}$ \\
\hline Stock Market & & $\begin{array}{l}\text { Average of crisis affected countries in 1997 } \\
\text { (Rationale: It is during this period that "hot } \\
\text { money" started getting out of the region.) }\end{array}$ \\
\hline $\begin{array}{l}\text { Composite Stock Price Index } \\
\text { (year-to-year change) }\end{array}$ & Bloomberg & $\begin{array}{l}\text { Average of crisis affected countries from } \\
\text { 1Q1995 to 4Q1997 }\end{array}$ \\
\hline Stock Price Earnings Ratio & Bloomberg & \multicolumn{2}{|l}{} \\
\hline
\end{tabular}

\section{Macroprudential Analysis}

The selected MPIs are compared to a set of country-specific threshold values on a monthly basis. A vulnerability signal is flashed when an observed outcome of an indicator crosses its threshold value. The higher the number of indicators flashing out signals at any given period indicates heightened vulnerability. Table 3 below provides a summary of the surveillance results.

\begin{tabular}{|c|c|c|c|c|}
\hline \multicolumn{5}{|c|}{$\begin{array}{l}\text { Table 3: Vulnerability signals by Indicator Category } \\
\text { Country } X\end{array}$} \\
\hline & 2002 & 2003 & $\begin{array}{c}1^{\text {st }} \text { Quarter (1Q) } \\
2004\end{array}$ & $\begin{array}{l}2^{\text {nd }} \text { Quarter (2Q) } \\
2004\end{array}$ \\
\hline Money, Credit and Interest Rates & 2 & 5 & 2 & 2 \\
\hline Banking & 11 & 8 & 2 & 1 \\
\hline $\begin{array}{l}\text { Public Finance, External Debt and } \\
\text { Financial Flows }\end{array}$ & 4 & 3 & 1 & 0 \\
\hline Trade and International Reserves & 3 & 5 & 1 & 1 \\
\hline Stock Market & 4 & 4 & 0 & 0 \\
\hline Total & 24 & 26 & 6 & 4 \\
\hline
\end{tabular}

The complete tabulation of the signals for each indicator over this period is given in Table 4. 


\begin{tabular}{|c|c|c|c|c|c|}
\hline \multicolumn{6}{|c|}{$\begin{array}{l}\text { Table 4. Vulnerability Signals by Each Indicators } \\
\text { Philippines }\end{array}$} \\
\hline & Source & 2002 & 2003 & 1Q2004 & 2Q2004 \\
\hline \multicolumn{6}{|l|}{ Money, Credit and Interest Rates } \\
\hline M2, y-o-y growth & EIU & 0 & 0 & 0 & 0 \\
\hline \multicolumn{6}{|l|}{ Domestic Credit } \\
\hline Growth, y-o-y & MPI table & 0 & 0 & 0 & 0 \\
\hline Ratio to GDP & MPI table & 0 & 0 & 0 & 0 \\
\hline Real Money Market Rate/Inter-Bank Rate & IFS, ARIC & 0 & 0 & 0 & 0 \\
\hline Lending Deposit rate spread & BSP & 1 & 3 & 1 & 1 \\
\hline Differential between Domestic and US real interest rate & IFS & 1 & 2 & 1 & 1 \\
\hline subtotal & & 2 & 5 & 2 & 2 \\
\hline \multicolumn{6}{|l|}{ Banking } \\
\hline \multicolumn{6}{|l|}{ Net Bank Profits } \\
\hline Return on Assets & MPI table & 1 & 0 & 0 & 0 \\
\hline \multicolumn{6}{|l|}{ Return on Equity } \\
\hline Total Bank Loans to Total Deposits & & 0 & 0 & 0 & 0 \\
\hline Credit to Private Sector, Ratio to GDP & IFS & 1 & 0 & 0 & 0 \\
\hline Central Bank Credit to the Banking System & MPI table & 0 & 0 & 0 & 0 \\
\hline \multicolumn{6}{|l|}{ Household Debt } \\
\hline Growth, y-o-y & MPI table & 1 & 1 & 0 & 0 \\
\hline Ratio to GDP & MPI table & 0 & 0 & 0 & 0 \\
\hline Real Estate Loans (Ratio to Total Loans) & MPI table & 4 & 3 & 1 & 0 \\
\hline Non-performing Loans (Ratio to Total Loans) & MPI table & 4 & 4 & 1 & 1 \\
\hline \multicolumn{6}{|l|}{ Liquid Assets to Short-term Liabilities } \\
\hline subtotal & & 11 & 8 & 2 & 1 \\
\hline \multicolumn{6}{|l|}{ Public Finance, External Debt and Financial Flows } \\
\hline Overall budget deficit to GDP & ARIC & 4 & 3 & 1 & 0 \\
\hline $\begin{array}{l}\text { Short-Term International Borrowing or External debt } \\
\text { with maturities one year or less }\end{array}$ & ARIC & 0 & 0 & 0 & 0 \\
\hline subtotal & & 4 & 3 & 1 & 0 \\
\hline \multicolumn{6}{|l|}{ Trade and International Reserves } \\
\hline Trade Balance to GDP & IFS & 0 & 1 & 0 & 0 \\
\hline Nominal exchange rate, yoy change & ARIC & 0 & 0 & 0 & 0 \\
\hline International Reserves (y-o-y growth) & IFS & 3 & 4 & 1 & 1 \\
\hline GIR in months of imports & ARIC & 0 & 0 & 0 & 0 \\
\hline subtotal & & 3 & 5 & 1 & 1 \\
\hline Stock Market & & & & 0 & 0 \\
\hline Composite Stock Price Index (y-o-y growth) & MPI table & 0 & 1 & 0 & 0 \\
\hline Stock Price Earnings Ratio & Bloomberg & 4 & 4 & 0 & 0 \\
\hline subtotal & & 4 & 5 & 0 & 0 \\
\hline TOTAL & & 24.00 & 26.00 & 6.00 & 4.00 \\
\hline
\end{tabular}




\section{Overall Assessment}

(i) The Philippines showed no major changes in the total number of vulnerability signals emitted over the surveillance period. It increased slightly from 24 signals 2001 to 26 in 2003. The first two quarters of 2004 already posted a total of 10 signals (Table 7). The number of indicators that flashed vulnerability signals did not decline significantly, indicating that existing causes of vulnerability still need to be addressed such as continuing concerns over excess liquidity and the fiscal deficit.

(ii) Of the five indicator categories, three had higher number of signals in 2003 compared to 2002 levels while the other two have gone down. Based on data from the first two quarters of 2004, it is possible that there will be no major deviation from 2003 except for Money, Credit and Interest Rates, which already has 4 signals in the first half of 2004 compared to 5 signals for the whole of 2003 (Table 7).

(iii) Only the ratio of non-performing loans to total loans persistently flashed vulnerability signals from 1Q 2002 until 2Q 2004. (Appendix 2)

(iv) Table 8 below shows indicators whose signals in 2003 are higher than 2002. These indicators were limited to lending-deposit rate spread, the differential between domestic and US real interest rates and the y-o-y growth of international reserves. However, the change in the number of vulnerability signals is quite minimal.

\begin{tabular}{|l|r|r|r|r|}
\hline \multicolumn{7}{|c|}{ Table 8: Macroprudential Indicators With Higher Number Of Vulnerability Signals } \\
In 2003 Compared To 2002 \\
Country X
\end{tabular}

\section{Money, Credit and Interest Rate}

(v) Of the six indicators under this category, only two gave out signals - the lending-deposit rate spread and the differential between US and domestic interest rates. Most of the signals occurred from 2003 onwards. Actual figures for the lending-deposit rate spread peaked at one percentage point above the threshold of $5.04 \%$ in $4 Q 2003$. It has already gone down since and is only slightly above the threshold by the 2Q2004.

(vi) The differential between US and domestic interest rates, on the other hand, has been rising steadily since the second half of 2003 , reaching $6.22 \%$ in 2Q2004, which is about 1.2 percentage points higher than the threshold. This is driven mainly by recent 
increases in key US interest rates and poses the risk of capital flight from the country as domestic assets become less attractive to investors.

(vii) The rest of the indicators in this category fell well below their threshold values. Domestic credit to GDP in particular, which is an important sign of banking fragility, has been relatively stable at around $55 \%$ since 2002 , but it is the indicator that is closest to the country's pre-crisis average (68\%).

\section{Banking}

(viii) Of the ten indicators in this category, eight have available data. Only two indicator account for the bulk of signals in this category namely, the ratios of real estate loans and non-performing loans (NPLs) to total loans.

(ix) NPLs account for the bulk of the signals flashed for this category and have persistently flashed signals since 2002. Although NPL share in total loans is still high, it has remained relatively stable since 2002 and has been declining since 1Q2003. It posted $13.77 \%$ as of $2 \mathrm{Q} 2004$, just two percentage points above the threshold.

(x) The ratio of real estate loans to total has the next largest share in the total number of signals for this category. It has emitted signals since 1Q 2002, except for 3Q 2003. Nevertheless, actual figures are quite stable. It hovers at less than one percentage point higher than the $11.6 \%$ threshold. It also does not differ much from the Philippines' precrisis average of $12.14 \%$.

(xi) Net banks profit, measured by return on assets and equity, is available only on an annual basis. It gave out a signal in 2002 and none in 2003. However, even with an ROA of 1.2 in 2003, bank profitability basically continued to perform poorly given that it is only slightly above the threshold of $1.07 \%$ and significantly below the country's pre-crisis average of $1.92 \%$. This may be due in part to tighter prudential regulation, a large proportion of NPLs and weak business activities.

(xii) Since household debt has no available pre-crisis data, Philippine figures are compared to Korea's since the latter underwent a consumer debt driven crisis in 2003. As a ratio of GDP, this indicator poses no threat to the Philippines at the moment because it has a relatively low level of household credit, ranging from 1.6 to 2.26 over 2001 to the first half of 2004. This is just a fraction of Korea's average pre-crisis (from 2001 to 2002) figure of $54.7 \%$. Likewise, household credit growth is not an immediate source of vulnerability. It exhibited strong, double-digit growth in the range of 20\%-34\% from 2Q 2002 to 1Q 2003 which is comparable to Korea's $24.85 \%$. However, growth decelerated to single-digit figures thereafter and even declined by 11\% in 1Q 2004.

(xiii) Credit to the private sector relative to GDP has generally been on a downward trend. It was around 72\% in 1Q 2001 (the only time that it breached the threshold of 70\%), gradually declined over the years and stands at about $59 \%$ by $2 Q 2004$.

(xiv) Although the number of signals in this category did not decline significantly, giving out a total of 11 signals in 2002, 8 in 2003 and 3 in the first half of 2004, actual figures show a definite improvement in the stability of the sector and a general decline in vulnerability despite weak profitability. 


\section{Public Finance, External Debt and Financial Flows}

(xv) Only the budget deficit flashed in this indicator category almost throughout period. The threshold value is set at 3\% of GDP deficit, which is the benchmark, set by the EU for its members. For the most part, this indicator is much higher than the threshold ranging from $5-6 \%$. The deficit stood at $3.9 \%$ of GDP by the end of 2002 , inching upward to $4.64 \%$ by the end of 2003 . This indicates that government efforts to curb excessive public spending and to improve revenue generation have so far failed to seal the gaping fiscal hole.

(xvi) Despite the growing deficit, indicators for short-term external debt had flashed no signal. It remained stable and well below the country's pre-crisis average over the observation period.

\section{Trade and International Reserves}

(xvii) This set of indicators is generally healthy for Country X. From 2001 to 2003, international reserves (y-0-y growth) account for almost all the signals in this category. However, there is no indication of vulnerability in this area because when reserves are measured in terms of months of imports it is significantly above the threshold of 4 months.

(xviii) Trade balance to GDP only gave out one signal throughout 2002 to the first half of 2004 . It fell slightly below the threshold of $-0.89 \%$ in $2 \mathrm{Q} 2003$. Clearly, there is no immediate threat in this area since remained above the threshold for the most part in the last three years.

(xix) Supporting data show that there is no immediate cause for concern in this category. Although the total number of signals rose from 3 in 2002 to 5 in 2003, it already dropped to 1 in $1 \mathrm{Q}$ and 0 in the $2 \mathrm{Q}$ of 2004.

\section{Stock Market}

(xx) The two indicators in this category both gave out signals over 2002- to 2004 but most of it was given out by the stock price-earnings ratio. This particular indicator was consistently above the threshold value of $22 \%$ (derived from the five-crisis affected countries average in 1997) since the 1Q2002 to 4Q2003. It peaked at 400\% in 3Q2002 and started declining since then. By the 1Q2004 it has already dropped to $18.8 \%$ and declined further to $16.5 \%$ by the $2 \mathrm{Q}$. However, the stock price index has been relatively flat since 2001, implying that corporate earnings have been weak over the period when it gave out signals.

(xxi) The y-o-y growth of the composite stock price index only gave out one signal throughout the period covered by this paper. It declined by $26 \%$ in 1Q 2003, breaching the $-23.25 \%$ threshold. This may be the market's reaction to the exceptionally high stock priceearnings two quarters before it. It also declined in the last quarter of 2003 although it did not breach the threshold.

\section{Business Tendency Survey (BTS)}

(xxii) It appears that business sentiment was generally improving towards 2003, since the number of signals for all five indicators in this category were declining. However, the tide 
has turned again 2004 as business sentiment showed a more cautious outlook as international interest and oil prices and domestic budget deficits continue to rise. (Table 9)

\begin{tabular}{|l|c|c|c|c|}
\hline \multicolumn{5}{|c|}{ Table 9. Business Expectation Survey Indicators } \\
\hline & $\mathbf{4 Q ^ { 6 } \mathbf { 2 0 0 3 }}$ & $\mathbf{1 Q 2 0 0 4}$ & $\mathbf{2 Q 2 0 0 4}$ & $\mathbf{3 Q 2 0 0 4}$ \\
\hline Current Business Situation & 31.10 & 6.50 & 25.40 & 26.90 \\
\hline Expected Business Situation (next 6 months) & 20.00 & 30.60 & 36.40 & 50.20 \\
\hline Stock of Finished Products & & & & \\
\hline$\quad$ Industry & & 15.00 & & 12.00 \\
\hline$\quad$ Wholesale and retail trade & & $(5.70)$ & & 21.90 \\
\hline Employment (present situation)-here next quarter & $(2.00)$ & $(2.80)$ & 4.90 & 16.80 \\
\hline Financial Situation (present situation) & $(27.50)$ & $(32.80)$ & $(31.40)$ & $(25.70)$ \\
\hline
\end{tabular}

Source: Bangko Sentral ng Pilipinas

\section{Policy Analysis and Recommendations}

(xxiii) It is clear that the most pressing concerns for this country are the presence of high nonperforming loans and the substantial fiscal deficit because its indicators have given persistent warning signals. This is especially true for the latter because actual values are significantly higher than its threshold value.

(xxiv) Existing NPLs should be restructured at the earliest so that that lending to the private sector could be strengthened. High NPLs discourages financial institutions from expanding lending operations that choose to invest their funds in government securities and the like instead. This is evident with the decline of credit to the private sector relative to the size of the economy.

(xxv) Restraining the budget deficit, however, will be a bigger challenge. There is a pressing need to tighten expenditure and, more importantly, to improve revenue collection in order to reign in the deficit before it becomes unmanageable, especially in light of increasing global interest rates. The government would need to improve implementation of current tax laws, particularly in terms of addressing tax evasion, and legislate new taxes in order to improve revenue generation. On the expenditure side, the government would have to streamline the budget and trim-down cost.

(xxvi) In terms of potential vulnerability, the share of real estate loans may need to be monitored more closely since it breached the threshold consistently except for one period over 2003-2004 and is now approaching pre-crisis levels. The rise in oil prices and global interest rates may lead to an economic downturn that may soften demand for real estate and compromise the stability of banks that provided financing for these projects.

\section{Concluding Remarks}

Systemic financial and currency crises in several developing counties and their contagion effect as well as in some developed countries and ongoing worldwide financial crisis originated in USA in 2008 revealed the limitations of the current state of the monetary and financial monitoring system in comprehensively addressing financial vulnerability leading to crisis. A crisis can cause economic, social, and political problems. The cost of a financial crisis could be severe as a

\footnotetext{
${ }^{6}$ Fourth Quarter data
} 
result of severe reserve losses, output decline and poverty. In order to prevent financial turmoil and its contagion effect, monitoring the financial sectors as well as spillover effects of weaknesses to the real sector assumes great importance. The monitoring system should be able to detect the magnitude and nature of the economic and financial vulnerability at an early stage and suggest appropriate policy actions to address them, thereby preventing a crisis.

There is no universally accepted standard or system for monitoring financial vulnerability. The development of MPIs for monitoring financial vulnerability is still a working in progress. It is almost impossible to predict the probability, timing, and kind of a crisis that will occur even with significant progress in techniques for MPI analysis, especially in EWS models. It may be better to use macroprudential analysis in crisis prevention rather than crisis prediction. A monitoring system should be cost-effective and not too complicated so that most countries can implement it for their high frequency monitoring.

The proposed system in this paper can provide an initial framework for using MPI to detect vulnerability in the economy and the financial sector. As some crucial indicators do not have long time-series data available (i.e., corporate sector data, level of non-performing loans, household debt, international bank borrowing with less than one year maturity), it is not possible to compute threshold values. For these indicators, separate trend analysis on recent data should be performed to detect any large fluctuations or deviations from the trend.

The vulnerability signals provided by the proposed framework can direct attention to particular issues or problems. Trend analysis can then be used to confirm if the indicators are indeed showing signs of vulnerability that may lead to an impending crisis or whether it is simply a result of institutional or structural changes. In order to avoid the virulence of the contagion among neighboring countries, there is a need for further strengthening of the regional surveillance mechanism, particularly the peer review process.

The most difficult part of monitoring is to analyze, interpret, and translate the information contained in these indicators and their trends into something that could help direct policymakers and decision makers to appropriate policy actions. The interpretations discussed in this paper are meant to be starting points for national authorities to develop more country-specific monitoring schemes that take into account a country's specific needs and circumstances.

Another important task is to provide the analytical groundwork in devising the appropriate benchmarks or threshold values for high frequency data. However, it is to be noted that the macroprudential analysis should focus not only one symptom-whether a MPI is above or below the threshold value - but on the underlying sources of chronic vulnerability. This calls for further analysis of related data or indicators.

Each indicator should be updated regularly (preferably fortnightly) and compared to its threshold value. In terms of policy action, it is more important to monitor how near the figures are to their threshold value rather than wait for them to breach the threshold. It is important, in this sense, to establish certain rules of thumb when interpreting surveillance results because there may be several options available. For example, one can opt for a disinflationary policy to avoid sharp deviations in real exchange rate relative to its historical trend, or adopt a policy that avoids unsustainable nominal exchange rate appreciation.

Despite the appeal of using MPI analysis, its limitation should be recognized. The first major drawback of using MPI is its assumption that an economy has a consistent and regular pattern prior to a crisis. It relies largely on historical precedents but because of differences in the origin, 
severity, and timing of crises, it is possible that indicators that were useful for one in the past may not necessarily be so in the future. Triggering events for different types of crisis also vary, i.e. indicators for a balance of payments crisis may not necessarily be as effective when used to predict a banking crisis. Therefore, the process of identification of MPIs should be dynamic in nature in order to assess the need for new indicators. Emergence of vulnerabilities in a new sector or a new type of vulnerability calls for the inclusion of new MPIs in the surveillance process. In view of the ongoing financial crisis, new MPIs concerning new sectors and institutions witnessing vulnerabilities such as off-balance activities of commercial and investment banks including risky financial derivative products, large financial institutions and housing mortgage markets need to be included in the surveillance process.

Second, MPIs that are useful for crisis prediction in one country may not be for another, because of differences in the stage of economic and financial development, giving rise to significant variations in accounting and prudential standards, level of financial sophistication, and resilience of institutions, among others. However, tailor-fitting the set of MPIs to suit the unique economic characteristics of each country would give rise to the issue of cross-country comparability.

Third, structural breaks in the time series arising due to changes in regulations or regimes can complicate MPI analysis. In light of these limitations, caution ought to be exercised in analyzing MPIs or more specifically, applying one smaller core set of leading indicators to a group of countries, and encouraging compilation of additional indicators that apply to special situations particular to each country.

Fourth, there are measurement problems in capturing qualitative information. For instance, poor banking supervision, which is identified as a major factor in the Asian crisis, is difficult to quantify and qualitative assessments may vary significantly. Other factors that are possibly important in predicting a crisis but are difficult to measure include the quality of corporate governance, independence of the central bank, reliability of the legal system, political stability, and other institutional qualities.

Existing methods for MPI analysis have their own advantages but much still needs to be done to improve these techniques. For instance, there is no universally accepted or independently determined set of benchmark or threshold values for each MPI, yet it is an important feature of economic and financial surveillance, and is even used in EWS models to predict the occurrence of a crisis (Bhattacharyay, 2004).

Further development of deeper, transparent and more liquid financial markets; strengthening financial institutions and their supervision and regulation; more transparent and efficient monetary and financial policies will be essential to prevent future crises, financial instability, and minimize the after-effects of a crisis in the region. Measures such as greater central bank independence, strengthening prudential supervision and regulation of financial markets including large financial institutions, improving legal infrastructure, enhancing corporate governance and greater policy transparency need to be exercised.

Finally, the last segment of this paper focuses on some of quantitative aspects of crisis monitoring. However, it is important to keep in mind the importance of the qualitative aspecs of crisis monitoring models should be allowed to make decision for us. However, models are just tools to help management in decision making. Management decisions aided by objective quantitative models help reduce vulnerability and economic losses, but the experience and judgment of the analyzer is the most important factor. There are several qualitative factors in a 
model, such as the parameters and modeling assumptions used, as well as choices that relate to characteristics of the underlying data and the historical period form which the data was drawn. Vulnerability management tools, including the judgment and experience of the technical staff need to be strengthened continuously. Also macroprudnetial analysis requires an interdisciplinary team with financial economists, banking and financial experts, financial institutions supervision experts, accountants, economists, econometricians, corporate sector experts, statisticians etc. The scope of capacity building in monitoring is still wide among developing countries. Technical training should be provided to ministries of finance, central banks, capital market supervisory authorities and other relevant supervisory authorities to enable them to perform meaningful interpretation and analysis of MPIs. Effective monitoring calls for a high degree of experience in analyzing the quantitative MPIs, coupled with informed judgment on the adequacy of the institutional and regulatory framework of the concerned country.

The virulence of the contagion of a systemic crisis among neighboring countries as well as among trade partners shows the importance of an appropriate and effective regional surveillance mechanism, including the peer review process to prevent or detect future crises, and financial instability or to minimize their impacts in the region. At the same time, the worldwide financial crisis of 2008-2009 calls for an effective global surveillance system supported by appropriate and effective regional and national surveillance systems. 


\section{References:}

Agenor. P. Does Globalization Hurt the Poor? World Bank WP 2922, WB, 24 October 2002.

Agenor Pierre-Richard, Benefits and Costs of International Financial Integration: Theory and Facts, World Bank, 25 February 2003.

Baldacci. E., Mello, L. D., Inchauste., G, Financial Crisis, Poverty and Income Distribution, IMF Working Paper, WP/02/4, IMF, January 2002

Berg, A. and Pattillo, C., 1999a, "Are Currency Crises Predictable? A Test", IMF Staff Papers; 46(2), June, pp. 107-38.

Berg, A. and Pattillo, C., 1999b, "Predicting Currency Crises: The Indicators Approach and an Alternative", Journal of International Money and Finance; 18(4), August, pp. 561-86.

Berg A., Borenzstein E. and Pattilo C., 2004. "Assessing Early Warning Systems: How They Worked in Practice", IMF Working Paper, WP/04/52, March.

Berg, Andrew, Eduardo Borensztein, Gian Maria Milesi-Ferretti, and Catherine Pattillo, 1999.

"Anticipating Balance of Payments Crises: The Role of Early Warning Systems," IMF

Occasional Paper 186.

Bhattacharyay, B., 2001. "Strengthening and Harmonization of MPIs for monitoring financial asset markets in Asia and Pacific", presented at the concluding workshop of Regional Technical Assistance 5869, Manila, Asian Development Bank,16-18 May 2001.

Bhattacharyay, B. 2004, "A Quantitative Framework for Macroprudential/Financial Soundness Analysis for Monitoring Economic and Financial Vulnerability", Irving Fisher Committee (ifc) Bulletin, No. 19, November, 2004, Brussels.

Bhattacharyay, B., and Nerb, G., 2002. "Leading Indicators for Monitoring the Stability of Asset and Financial Markets in the Asia and Pacific", Asia Pacific Development Journal, Vol. 9, No. 2, United Nations ESCAP, Bangkok, December.

Bhattacharyay, B., De, P., 2009, "Global Financial and Economic Crisis and Asia's Trade Potential", a paper presented at Brown Bag Lunch Seminar at the Research Institute of Economy, Trade and Industry, , http://www.rieti.go.jp/en/events/bbl/09081301.html, Tokyo, September,

Blaschke, W., Mathew. T. J., Giovanni. M., and Soledad. M. P., 2001, "Stress testing of Financial Systems: An overview of issues, methodologies and FSAP experiences", IMF Working Paper 01/88, IMF, Washington, D. C.

Bordo, Michael, Barry Eichengreen, Daniel Klingebiel and Soledad Maria Martinez Peria, 2001. "Is the Crisis Problem Growing More Severe?" Economic Policy 32.

Chen, Shaohua, and Marin Ravallion, "How Did the World's Poorest Fare in the 1990s?", 2001, Policy Research Paper no. 1620, Washington, D.C., World Bank. 
Cihak, M., "Stress Testing: A Review of Concepts", 2003, paper written within the framework of the Czech National Bank Research Project No. B6/2003 and presented in a seminar at Czech National Bank, December 2003.

Davis, E. Phillip, 1999. "Financial data needs for macroprudential surveillance - What are the key indicators of risks to domestic financial stability?", Centre for Central Banking Studies, Bank of England.

Edison, H., 2000. "Do indicators of financial crises work? An evaluation of an early warning system." Board of Governors of the Federal Reserve System. International Finance Discussion Papers, 675.

Eichengreen, B., Rose, A., and Wyplosz, C. 1995, "Exchange Market Mayhem: The Antecedents and Aftermaths of Speculative Attacks", Economic Policy, 21, pp. 249-312.

Estanislao Jesus P., Manzano George N., and Pasadilla Gloria O., 2000. "The Asian Financial Crisis: An East Asian Perspective," Asian-Pacific Economic Literature, May.

Evans, O., Leone, A., Gill, M. and Hilbers, P., 2000. "Macroprudential Indicators of Financial System Soundness", IMF Occasional Paper, 192.

Fratzscher. M. "On Currency Crisis and Contagion", 2002, Working Paper No. 139, European Central Bank, Frankfurt, April

Goldstein, M., Kaminsky, G. and Reinhart, C., 2000. Assessing Financial Vulnerability, An Early Warning System for Emerging Markets, Institute for International Economics, June.

International Monetary Fund 2001a, Macroprudential Analysis: Selected Aspects Background Paper, June 7, IMF, Washington, D. C.

International Monetary Fund, 2001b, "Financial Sector Assessment Program (FSAP): A Review: Lessons from the Pilot and Issues Going Forward, Available via the internet http:// www. Imf.org/np/fsap/2001/review.htm, IMF, Washington, D. C.

International Monetary Fund and the World Bank, 2003, Analytical Tools of FSAP, http://www.imf.org/exteranl/np/fsap/2003/022403a.pdf.

International Monetary Fund, 2004, "Compilation Guide on Financial Soundness Indicators", IMF, Washington, D. C.,

Jones. T. M., Hilberts. P., and Slack. L. G., "Stress Testing Financial Systems: What to do When Governors Calls, IMF Working Paper, WP/04/127, IMF. Washington D.C., July

Kaminsky, G., Lizondo, S. and Reinhart, C., 1998. "Leading Indicators of Currency Crises", IMF Staff Papers, 45, No. 1, pp. 1-48.

Kaminsky, G. and Reinhart, C., 1999. "The Twin Crises: The Causes of Banking and Balanceof-Payments Problems", American Economic Review; 89(3), , pp. 473-500, June.

Kaminsky, G. and Reinhart, C. 2000, "On Crises, Contagion, and Confusion"; Journal of International Economics; 51(1), pp. 145-68, June. 
Krugman, P., 1979. "A Model of Balance of Payments Crises". Journal of Money Credit and Banking, 11: 311-28.

Prasad E., Rogoff K., Wei S.J., and Kose M.A., Effects of Financial Globalization on Developing Countries: Some Empirical Evidence, IMF, 17 March 2003.

Pesenti, Paolo and Tille Cedric, 2000. The Economics of Currency Crises and Contagion: An Introduction. Federal Reserve Bank of New York Economic Policy Review, September, pp 3-16.

Salvatore, D., 1999. "Could the Financial Crisis in East Asia Have Been Predicted?", Journal of Policy Modeling 21, no. 3: 341-47.

Sundararajan, V., et. al., 2002. "Financial Soundness Indicators: Analytical Aspects and Country Practices", IMF Occasional Paper No. 212.

United Nations Economic and Social Commission for Asia and the Pacific (UN ESCAP). 2000. Economic and Social Survey of Asia and the Pacific. New York. 


\section{Appendix 1: List of ADB Commonly Agreed MPIs (Bhattacharyay)}

\section{External Debt and Financial Flows}

1. Total Debt (\% of GDP) - ratio of total debt on nominal GDP.

$$
\text { a. } \quad \text {.. of which public debt }
$$

b. $\quad$.. of which private debt

2. Long Term Debt (\% of total debt) - ratio of long-term debt to total debt.

3. Short Term Debt (\% of GDP) - ratio of short-term debt to nominal GDP.

4. Short Term Debt (\% of total debt) - ratio of short-term debt to total debt.

5. Foreign Direct Investment (\% of GDP) - ratio of foreign direct (expressed as flows) investment to nominal GDP.

6. Portfolio Investment (\% of GDP) - ratio of portfolio investment (expressed as flows) to nominal GDP.

\section{Money and Credit}

7. $\mathrm{M} 1$ Growth (\%) - percent difference from previous period. $\mathrm{M} 1$ are liabilities of the monetary system consisting of currency and demand deposits.

8. M2 Growth (\%) - percent difference from previous period. M2 equals M1 plus quasi-money.

9. Money Multiplier (Ratio) - ratio of M2 to money base. Money base is the sum of currency in circulation, reserve requirement and excess reserves (with the central bank).

10. $\mathrm{M} 2$ (\% of International Reserves) - ratio of M2 to international reserves.

11. M2 (\% of GDP) - ratio of M2 to nominal GDP.

12. $M 2$ to international reserves growth - the growth rate of M2 over international reserves.

13. Quasi money (\% of GDP) - ratio of quasi money to nominal GDP.

14. Money Base Growth (\%) - percent difference from previous period.

15. Central Bank Credit to the Banking System - Central Bank's credit to the banking system.

16. Growth of Domestic Credit (\%) - percent difference from previous period. Consists of net claims from central government, claims on official entities and state enterprises, and claims of private enterprises and individuals.

17. Domestic Credit (\% of GDP) - ratio of domestic credit to nominal GDP.

18. Credit to Public Sector (\% of GDP) - ratio of credit to public sector to nominal GDP.

19. Credit to Private Sector (\% of GDP) - ratio of credit to private sector to nominal GDP.

20. Capital Adequacy Ratio (\%) - ratio of total capital on risk weighted assets (threshold value is $8 \%$ meaning that the ratio should not be less than this value). Ratio of Tier $1+$ Tier 2 capital to risk-weighted assets. Tier 1 capital includes issued and paid-up share capital, noncumulative preferred stock, and disclosed reserves from posttax retained earnings. Tier 2 capital can include a range of other entities. These are undisclosed reserves that passed through profit and loss account, conservatively valued revaluation reserves, revaluation of equities held at historical cost (at a discount), some hybrid instruments, general loan loss reserves (up to $1.25 \%$ of risk weighted assets), and subordinated term debt.

21. Liquidity Ratio (\%) - The ratio of commercial banks' liquid assets to total assets: (a) domestic liquid asset ratio and (b) foreign liquid asset ratio.

\section{Banking}

22. Bank Capital (\% of total asset) - ratio capital equity including reserves, profits, and loss to total assets.

23. Total Assets (\% of GDP) - ratio of total assets (as in Monetary Survey without interbank positions) to nominal GDP.

24. Growth of Total Assets (\%) - percent growth from previous period.

25. Share of 3 Largest Banks (\% of total asset)

26. Net Operating Profits (as \% of average assets)

27. Loan-Loss Provisions (\% of nonperforming loan) - ratio of loan loss provision to nonperforming loans 
28. Nonperforming Loans (\% of total loan) - ratio of nonperforming loans

29. Loans to the Key Economic Sector \& (\% of total loans)

30. Real Estate Loans (\% of total loans) - ratio of real estate loans to total loans.

31. Total Loans (\% of total deposits) - ratio of total loans to total deposits (i.e., demand deposits, savings deposits, time deposits.)

32. International liability from banks with maturities, total (mn US\$) - total international liability from commercial banks.

a. Short-term borrowing

b. Long-term borrowing - more than one year

33. International liability with maturities of one year and less ( $\mathrm{mn}$ US\$) - total international liability from commercial banks.

\section{Interest Rates (mean rate)}

(In case of monthly data average of daily rates, quarterly data monthly averages are to be applied)

34. Central Bank Lending Rate (a.o.p.) - end of period; rate at which the monetary authorities lend or discount eligible paper for deposit money banks.

35. Commercial Bank Lending Rate (a.o.p.)/ Prime Rate - average of period; ratio of commercial bank lending rate to prime rate. Prime rate refers to the short- and medium-term financing needs of the private sector.

36. Money Market Rate/Inter-Bank Rate (a.o.p.)- average of period; rate at which short-term borrowings are effected between financial institutions.

37. Short-term (3 mos.) Time Deposit Rates - interest rates of savings account held in a financial institution for 3 months or with the understanding that the depositor can withdraw only by giving a notice.

38. Long-term (12 mos.) Time Deposit Rates - interest rates of savings account held in a financial institution for 12 months or with the understanding that the depositor can withdraw only by giving a notice.

39. US\$ (international market)/Domestic Real Deposit Interest Rate - unweighted averages of offered rates quoted by at least five dealers early in the day for 3-month certificates of deposit in the secondary market.

40. Bond/Treasury Bill Yield (short-term) - yield to maturity of government bonds (short-term)

41. Bond/ Treasury Bill Yield (long-term) - yield to maturity of government bonds (long-term)

\section{Stock Markets and Bonds}

42. Foreign Share in Trading (\% of Total Volume of Trading) - proportion of foreign share in trading to total volume of trading.

43. Share of 10 Top Stocks in Trading (\% of Total Volume of Trading) - proportion of top 10 stocks in trading to total volume of trading.

44. Composite Stock Price Index (Capital City; in national currency unit) - equity price index of national capital city and expressed in national currency unit.

45. Composite Stock Price Index Growth (Capital City) - percent difference from previous period of equity price index; end of period and based on national currency unit.

46. Composite Stock Price Index (Capital City; in US\$)- equity price index of national capital city and expressed in US\$.

47. Market Capitalization (\% of GDP) - ratio of market capitalization to nominal GDP. Market Capitalization refers to the total market value of stocks or shares.

48. Stock Price Earning Ratio

\section{Trade Exchange and International Reserves}

49. Export Growth (\%) - export growth (fob) percent difference from previous period.

50. Import Growth (\%) - import growth (cif) percent difference from previous period.

51. Trade Balance (mn US\$) - difference between exports (fob) and imports (cif) 
52. Current account deficit/surplus (mn US\$)

53. Exchange Rate (average of period) - national currency unit to the US\$

54. Exchange Rate (end of period) - national currency unit to the US\$

55. Real Effective Exchange Rate - ratio of an index of the period average exchange rate of a currency to a weighted geometric average of exchange rate for the currencies of selected countries adjusted for relative movements in national prices of the home country and the selected countries. Refers to the definition used in IMF's International Financial Statistics series.

56. International Reserves (mn US\$) - international reserves include total reserves minus gold plus gold national valuation.

57. Growth of International Reserves (\%) - percent difference from previous period.

58. International Reserves (\% of imports) - ratio of international reserves to total imports.

\section{Business Survey Data (Manufacturing, Construction, Trade, Services)}

59. Assessment of Current Business Situation

60. Expectations on Business Situation in Next Months/Quarters

61. Limits to Business (Present Situation)

62. Stocks of Finished Products (Present Situation)

63. Assessment of Order Books

64. Selling Prices (Future Tendency)

65. Employment (Future Tendency)

66. Financial Situation (Present Situation)

67. Access to Credit (Present Situation)

Source: Bhattacharyay (2001)

\section{Appendix 2: Core Set of Leading MPI (Bhattacharyay and Nerb)}

\begin{tabular}{|lll|}
\hline \multicolumn{1}{|c|}{ Type of Indicator* } & \multicolumn{1}{c|}{ Title } & Characteristics \\
\hline Money and Credit & & leading \\
7. & M1 Growth (in \%) & leading \\
8. & M2 Growth (in \%) & leading \\
4. (additional) & M3 Growth (in \%) & coincident/leading \\
15. & Central Bank Credit To Banking System & coincident/leading \\
16. & Domestic Credit Growth (in \%) & coincident/leading \\
17. & Domestic Credit Growth (in \% of GDP) & \\
19. & Credit to Private Sector (in \% of GDP) & Leading \\
Banking & & Leading \\
26. & Net Bank Profits (in \% of total assets) & Leading \\
31. & Total Bank Loans (in \% of total deposits) & Leading \\
33. & International Borrowings with maturities one year and less \\
6. (additional) & (mn. US\$) & \\
Interest Rates & Real Estate Loans & Leading \\
36. & & \\
Stock Markets and Bonds & & Leading \\
44. & Money Market Rate/Inter Bank Rate &
\end{tabular}




\begin{tabular}{|c|c|c|}
\hline 47. & Market Capitalization (as \% of GDP) & Leading \\
\hline 48. & Stock Price Earning Ratio & Leading \\
\hline \multicolumn{3}{|c|}{ Trade Exchange and International Reserves } \\
\hline 55. & Real Effective Exchange Rate & coincident/leading \\
\hline 56. & International Reserves & leading \\
\hline \multicolumn{3}{|c|}{ Business Survey Results } \\
\hline 59. & Current Business Situation & \\
\hline & & coincident/leading \\
\hline 62. & $\begin{array}{l}\text { Expected Business Situation (next } 6 \text { months) } \\
\text { Stocks of Finished Products }\end{array}$ & coincident/leading \\
\hline 65. & Employment (Present Situation) & coincident/leading \\
\hline 66. & Financial Situation (Present Situation) & $\begin{array}{l}\text { coincident/leading } \\
\text { coincident/leading }\end{array}$ \\
\hline
\end{tabular}

Note: For reference purposes, the numbering is based on the list of ADB Commonly Agreed Indicators found in Table 4. Source: Bhattacharyay and Nerb (2002)

\section{Appendix 3 \\ Core Set of IMF FSIs}

\section{Deposit-takers \\ Capital}

Asset quality

Earnings and profitability

Liquidity

Sensitivity to market risk
Regulatory capital to risk-weighted assets Regulatory Tier I capital to risk-weighted assets Non Performing Loans net of provisions to capital Nonperforming loans to total gross loans Sectoral distribution of loans to total loans

Return on assets (net income to average total assets) Return on equity (net income to average equity) Interest margin to gross income Noninterest expenses to gross income

Liquid assets to total assets (liquid asset ratio) Liquid assets to short-term liabilities

Duration of assets

Duration of liabilities

Net open position in foreign exchange to capital 


\section{Encouraged Set of IMF FSIs}

Deposit-takers
Capital to assets

Large exposures to capital

Geographical distribution of loans to total loans

Gross asset position in financial derivatives to capital

Gross liability position in financial derivatives to capital

Trading income to total income

Personnel expenses to noninterest expenses

Spread between reference lending and deposit rates

Spread between highest and lowest interbank rate

Customer deposits to total (non-interbank) loans

Foreign currency-denominated loans to total loans

Foreign currency-denominated liabilities to total liabilities

Net open position in equities to capital

\begin{tabular}{ll}
\hline Other financial corporations & Assets to total financial system assets \\
Nonfinancial corporations & Assets to GDP \\
& Total debt to equity \\
& Return on equity \\
& Earnings to interest and principal expenses \\
& Net foreign exchange exposure to equity \\
& Number of applications for protection from creditors \\
Households & Household debt to GDP \\
Market liquidity & Household debt service and principal payments to income \\
& Average bid-ask spread in the securities market $1 /$ \\
Real estate markets & Average daily turnover ratio in the securities market $1 /$ \\
& Real estate prices \\
& Residential real estate loans to total loans \\
& Commercial real estate loans to total loans \\
\hline
\end{tabular}

$1 /$ Or in other markets that are most relevant to bank liquidity, such as domestic foreign exchange markets.

Source: Compilation Guide on Financial Soundness Indicators, IMF 2004 


\section{CESifo Working Paper Series}

for full list see www.cesifo-group.org/wp

(address: Poschingerstr. 5, 81679 Munich, Germany, office@cesifo.de)

2741 Yan Dong and John Whalley, A Third Benefit of Joint Non-OPEC Carbon Taxes: Transferring OPEC Monopoly Rent, August 2009

2742 Valentina Bosetti, Carlo Carraro and Massimo Tavoni, Climate Change Mitigation Strategies in Fast-Growing Countries: The Benefits of Early Action, August 2009

2743 Christina Felfe, The Willingness to Pay for Job Amenities: Evidence from Mothers' Return to Work, August 2009

2744 Jörg Franke, Christian Kanzow, Wolfgang Leininger and Alexandra Väth, Effort Maximization in Asymmetric N-Person Contest Games, August 2009

2745 Bruno S. Frey and Paolo Pamini, Making World Heritage Truly Global: The Culture Certificate Scheme, August 2009

2746 Frank N. Caliendo, Is Social Security behind the Collapse of Personal Saving?, August 2009

2747 Caterina Liesegang and Marco Runkel, Corporate Income Taxation of Multinationals and Fiscal Equalization, August 2009

2748 Chrysovalantou Milliou and Apostolis Pavlou, Upstream Horizontal Mergers and Efficiency Gains, August 2009

2749 Rüdiger Pethig and Christian Wittlich, Interaction of Carbon Reduction and Green Energy Promotion in a Small Fossil-Fuel Importing Economy, August 2009

2750 Kai Carstensen, Oliver Hülsewig and Timo Wollmershäuser, Monetary Policy Transmission and House Prices: European Cross-country Evidence, August 2009

2751 Olaf Posch, Explaining Output Volatility: The Case of Taxation, August 2009

2752 Beatrice Scheubel, Daniel Schunk and Joachim Winter, Don't Raise the Retirement Age! An Experiment on Opposition to Pension Reforms and East-West Differences in Germany, August 2009

2753 Daniel G. Arce, Dan Kovenock and Brian Roberson, Suicide Terrorism and the Weakest Link, August 2009

2754 Mario Larch and Wolfgang Lechthaler, Comparative Advantage and Skill-Specific Unemployment, August 2009

2755 Horst Raff and Nicolas Schmitt, Buyer Power in International Markets, August 2009 
2756 Seppo Kari, Hanna Karikallio and Jukka Pirttilä, The Impact of Dividend Taxation on Dividends and Investment: New Evidence Based on a Natural Experiment, August 2009

2757 Mirco Tonin and Michael Vlassopoulos, Disentangling the Sources of Pro-social Behavior in the Workplace: A Field Experiment, August 2009

2758 Nicole Grunewald and Inmaculada Martínez-Zarzoso, Driving Factors of Carbon Dioxide Emissions and the Impact from Kyoto Protocol, August 2009

2759 Yu-Fu Chen and Michael Funke, Booms, Recessions and Financial Turmoil: A Fresh Look at Investment Decisions under Cyclical Uncertainty, August 2009

2760 Jan-Egbert Sturm and Jakob de Haan, Does Central Bank Communication really Lead to better Forecasts of Policy Decisions? New Evidence Based on a Taylor Rule Model for the ECB, August 2009

2761 Larry Karp, Sacrifice, Discounting and Climate Policy: Five Questions, August 2009

2762 Marianna Belloc and Samuel Bowles, International Trade, Factor Mobility and the Persistence of Cultural-Institutional Diversity, August 2009

2763 Charles Noussair and Fangfang Tan, Voting on Punishment Systems within a Heterogeneous Group, August 2009

2764 Birgit Bednar-Friedl and Karl Farmer, Internationally Coordinated Emission Permit Policies: An Option for Withdrawers from the Kyoto Protocol?, August 2009

2765 Pierre M. Picard and David E. Wildasin, Labor Market Pooling, Outsourcing and Labor Contracts, August 2009

2766 Stefan Voigt and Lorenz Blume, The Economic Effects of Federalism and Decentralization - A Cross-Country Assessment, August 2009

2767 David S. Jacks, Christopher M. Meissner and Dennis Novy, Trade Booms, Trade Busts, and Trade Costs, August 2009

2768 Mario Jametti and Thomas von Ungern-Sternberg, Hurricane Insurance in Florida, August 2009

2769 Alessandro Balestrino, Kind of Black: The Musicians' Labour Market in Italy, August 2009

2770 Yosr Abid Fourati and Cathal O’Donoghue, Eliciting Individual Preferences for Pension Reform, August 2009

2771 Christian Breuer and Chang Woon Nam, VAT on Intra-Community Trade and Bilateral Micro Revenue Clearing in the EU, August 2009

2772 Choudhry Tanveer Shehzad, Jakob De Haan and Bert Scholtens, Growth and Earnings Persistence in Banking Firms: A Dynamic Panel Investigation, August 2009 
2773 Erdal Yalcin, Uncertain Productivity Growth and the Choice between FDI and Export, August 2009

2774 Klaus Abberger, Wolfgang Nierhaus and Shynar Shaikh, Findings of the Signal Approach for Financial Monitoring in Kazakhstan, September 2009

2775 Sascha O. Becker, Francesco Cinnirella and Ludger Woessmann, The Trade-off between Fertility and Education: Evidence from before the Demographic Transition, September 2009

2776 Thomas Aronsson and Erkki Koskela, Optimal Income Taxation, Outsourcing and Policy Cooperation in a Dynamic Economy, September 2009

2777 Joel Slemrod, Old George Orwell Got it Backward: Some Thoughts on Behavioral Tax Economics, September 2009

2778 Cagri Seda Kumru and Athanasios C. Thanopoulos, Social Security Reform and Temptation, September 2009

2779 Alessandro Bucciol and Roel M. W. J. Beetsma, Inter- and Intra-generational Consequences of Pension Buffer Policy under Demographic, Financial and Economic Shocks, September 2009

2780 Eduardo Strube and Marcelo Resende, Complementarity of Innovation Policies in the Brazilian Industry: An Econometric Study, September 2009

2781 Henry Tulkens and Vincent van Steenberghe, "Mitigation, Adaptation, Suffering": In Search of the Right Mix in the Face of Climate Change, September 2009

2782 Maria L. Loureiro, Anna Sanz-de-Galdeano and Daniela Vuri, Smoking Habits: Like Father, Like Son, Like Mother, Like Daughter, September 2009

2783 Momi Dahan, Tehila Kogut and Moshe Shalem, Do Economic Policymakers Practice what they Preach? The Case of Pension Decisions, September 2009

2784 Eytan Sheshinski, Uncertain Longevity and Investment in Education, September 2009

2785 Nannette Lindenberg and Frank Westermann, How Strong is the Case for Dollarization in Costa Rica? A Note on the Business Cycle Comovements with the United States, September 2009

2786 Leif Danziger, Noncompliance and the Effects of the Minimum Wage on Hours and Welfare in Competitive Labor Markets, September 2009

2787 Gerlinde Fellner, Rupert Sausgruber and Christian Traxler, Testing Enforcement Strategies in the Field: Legal Threat, Moral Appeal and Social Information, September 2009

2788 Gabriel J. Felbermayr, Mario Larch and Wolfgang Lechthaler, Unemployment in an Interdependent World, September 2009 
2789 Sebastian G. Kessing, Federalism and Accountability with Distorted Election Choices, September 2009

2790 Daniel Gros, Global Welfare Implications of Carbon Border Taxes, September 2009

2791 Louis N. Christofides, Michael Hoy and Ling Yang, The Gender Imbalance in Participation in Canadian Universities (1977-2005), September 2009

2792 Jan K. Brueckner and Robert W. Helsley, Sprawl and Blight, September 2009

2793 Vidar Christiansen and Stephen Smith, Externality-correcting Taxes and Regulation, September 2009

2794 John Beirne, Guglielmo Maria Caporale, Marianne Schulze-Ghattas and Nicola Spagnolo, Global and Regional Spillovers in Emerging Stock Markets: A Multivariate GARCH-in-mean Analysis, September 2009

2795 Rüdiger Pethig and Frieder Kolleß, Asymmetric Capital-Tax Competition, Unemployment and Losses from Capital Market Integration, September 2009

2796 Ngo Van Long, Horst Raff and Frank Stähler, Innovation and Trade with Heterogeneous Firms, September 2009

2797 Margit Osterloh and Bruno S. Frey, Research Governance in Academia: Are there Alternatives to Academic Rankings?, September 2009

2798 Thiess Buettner and Clemens Fuest, The Role of the Corporate Income Tax as an Automatic Stabilizer, September 2009

2799 Annette Alstadsæter, Measuring the Consumption Value of Higher Education, September 2009

2800 Peter Friedrich, Chang Woon Nam and Janno Reiljan, Local Fiscal Equalization in Estonia: Is a Reform Necessary?, September 2009

2801 Evžen Kočenda and Jan Hanousek, State Ownership and Control in the Czech Republic, September 2009

2802 Michael Stimmelmayr, Wage Inequality in Germany: Disentangling Demand and Supply Effects, September 2009

2803 Biswa N. Bhattacharyay, Towards a Macroprudential Surveillance and Remedial Policy Formulation System for Monitoring Financial Crisis, September 2009 